\title{
Living income benchmarking of rural households in low-income countries
}

\author{
Gerrie W. J. van de Ven ${ }^{1}$ (D) - Anne de Valença ${ }^{2} \cdot$ Wytze Marinus $^{1} \cdot$ Ilse de Jager ${ }^{3} \cdot$ Katrien K. E. Descheemaeker $^{1}$ (D) \\ Willem Hekman ${ }^{1} \cdot$ Beyene Teklu Mellisse ${ }^{4} \cdot$ Frederick Baijukya $^{5} \cdot$ Mwantumu Omari $^{5} \cdot$ Ken E. Giller ${ }^{1}$ (D)
}

Received: 16 March 2020 / Accepted: 17 August 2020 / Published online: 28 September 2020

(C) The Author(s) 2020

\begin{abstract}
The extreme poverty line is the most commonly used benchmark for poverty, set at US\$ 1.90 by the World Bank. Another benchmark, based on the Anker living wage methodology, is the remuneration received for a standard work week necessary for a worker to meet his/her family's basic needs in a particular place. The living wage concept has been used extensively to address incomes of plantation workers producing agricultural commodities for international markets. More recently intense discussion has emerged concerning the 'living income' of smallholder farmers who produce commodities for international supply chains on their own land. In this article we propose a simple method that can be used in all types of development projects to benchmark a rural 'living income'. We launch the Living Income Methodology, as adapted from the Living Wage Methodology, to estimate the living income for rural households. In any given location this requires about one week of fieldwork. We express it per adult equivalent per day (AE/day) and data collection is focused on rural households and their immediate surroundings. Our three case studies showed that in 2017 in Lushoto District, rural Tanzania, the living income was US\$ PPP 4.04/AE/day, in Isingiro District, rural Uganda, 3.82 and in Sidama Zone, rural Ethiopia, 3.60. In all cases, the extreme poverty line of US\$ PPP 1.90 per capita per day is insufficient to meet the basic human rights for a decent living in low-income countries. The Living Income Methodology provides a transparent local benchmark that can be used to assess development opportunities of rural households, by employers in rural areas, including farmers hiring in labour, while respecting basic human rights on a decent living. It can be used to reflect on progress of rural households in low-income countries on their aspired path out of poverty. It further provides a meaningful benchmark to measure progress on Sustainable Development Goal 1, eliminating poverty, and 2, zero hunger and sustainable food systems, allowing for consideration of the local context.
\end{abstract}

Electronic supplementary material The online version of this article (https://doi.org/10.1007/s12571-020-01099-8) contains supplementary material, which is available to authorized users.

Gerrie W. J. van de Ven

gerrie.vandeven@wur.nl

Anne de Valença

annedevalenca@gmail.com

Wytze Marinus

wytze.marinus@wur.nl

Ilse de Jager

dejager.ilse@gmail.com

Katrien K. E. Descheemaeker

katrien.descheemaeker@wur.nl

Willem Hekman

hekmanwillem@gmail.com

Beyene Teklu Mellisse

beyteklu@gmail.com
Frederick Baijukya

f.baijukya@cgiar.org

Mwantumu Omari

m.omari@cgiar.org

Ken E. Giller

ken.giller@wur.nl

1 Plant Production Systems, Wageningen University, PO Box 430, Wageningen, The Netherlands

2 World Wildlife Fund, PO Box 7, Zeist, The Netherlands

3 Human Nutrition and Health, Wageningen University, PO Box 17, Wageningen, The Netherlands

4 College of Agriculture, Hawassa University, Hawassa, Ethiopia

5 International Institute of Tropical Agriculture (IITA), PO Box 10, Duluti, Arusha, Tanzania 
Keywords Poverty line $\cdot$ Smallholder farms $\cdot$ Ethiopia $\cdot$ Tanzania $\cdot$ Uganda

\section{Introduction}

Sustainable Development Goal (SDG) 1 aims to eliminate poverty by 2030. SDG 2 addresses zero hunger and sustainable food systems (United Nations General Assembly 2015). While the elimination of poverty is a noble goal, the aspirations of poor people are to rise above the poverty line and to educate their children, receive fair payments for their labour and products. Agriculture is closely linked to both SDGs. It contributes to food security and income to escape poverty. However, the margins in supply chains from farmers to retailers are unevenly distributed, with farmers least represented. The need to address social injustice in international supply chains of key agricultural commodities such as tea and coffee has led to an increasing focus on the 'living wage' for plantation workers. An extension of this approach to include smallholder farmers who produce such commodities on their own farms, rather than through paid employment on plantations is captured in the concept of the 'living income'. How to benchmark such a 'living income' is the focus of our approach presented here.

The most commonly used benchmark for poverty is the international poverty line. The international or extreme poverty line for low-income countries was set at US\$ Purchasing Power Parity (PPP) 1.90 per capita per day in the year 2011 (World Bank 2015b). It is based on the national poverty lines of the 15 poorest economies in the world in 2005 (Chen and Ravallion 2010) and adapted to increasing price levels in 2011 (World Bank 2015b). The 'costs of basic needs approach' is widely used to establish the national poverty lines (World Bank 2015a). It complies with the definition of a decent living (Jolly 1976; World Bank 2015a), although for the non-food part, an objective measure is difficult to find. A decent living is a basic human right, defined in Article 25.1 of The Universal Declaration of Human Rights as "all people have the right to a standard of living adequate for the health and well-being of himself and of his family, including food, clothing, housing and medical care and necessary social services, and the right to security in the events [...] beyond his control" (United Nations General Assembly 1948). In addition, everyone has the right to at least elementary education (Article 26.1). However, methods and type of data collected often partial - differ in national statistics among countries, complicating comparison (Ferreira et al. 2016; World Bank 2015a). Aside from this and other methodological drawbacks (World Bank 2018b; Ferreira et al. 201; World Bank 2015a) the poverty line of US\$ 1.90 (PPP 2011) seems to be a robust benchmark for low-income countries (Jolliffe and Prydz 2016). Despite the fact that eliminating poverty would be a major achievement for humanity, US\$ 1.90 per day is deemed the to be the absolute minimum, also referred to as the extreme poverty line. For lower-middle income countries the poverty line is set at US\$ 3.20 (experessed in PPP 2011). This also serves as a moderate poverty line for low-income countries (Jolliffe and Prydz 2016).

Other well-known benchmarks are the minimum wage and the living wage. Several International Labour Organisation (ILO) conventions and other statements point to the international agreement on the right to a decent minimum wage or living wage (ILO 2008; United Nations 2007; United Nations General Assembly 1948, art 23). A living wage is the wage keeping a worker and his family out of poverty. A minimum wage is more of a political instrument, based on the prevailing economic situation in a country at national scale. Ideally it should not be below the living wage, but most low-income countries do not have the political power and financial means for this (Croes and Vermeulen 2016). Based on their review, Croes and Vermeulen (2016) conclude that no agreed international system or standard is available for determining a fair minimum wage.

In rural areas in low-income countries often complex socioeconomic relations prevail. Self-consumption of home produced foods is often around $50 \%$ of the households' food requirements (FAO 2020). This could argue for a living income lowered with the value of home-produced food. However, food produced on-farm and consumed by the household represents a monetary value, a remuneration for production costs, including labour. For home consumption, although costs per unit are lower, farmers have to produce more volume compared with what they would buy, as losses in the phase of production and storage are much higher than for purchased food; 19\% for sub-Saharan Africa (Gustavsson et al. 2011). Poor farmers often have to sell their crop just after harvest, as they need cash for instance for school fees. Due to the oversupply at harvest time, prices in that period are low. In the hunger season, these poor households have to buy their food at higher prices (Leonardo et al. 2015). Often labour is not paid in cash but in kind, as food. Labour is also shared or hired out, sometimes at the expense of their own production (Leonardo et al. 2015). Other sources often contribute to household income, such as petty trade, off-farm wages, either in- or outside agriculture, and remittances from family members working in cities or abroad. Infrastructure and remoteness of rural areas are important factors for market access and as such for local food prices (Mellisse et al. 2017).

In the real world all these factors vary widely and numerous combinations exist. In our search for a simple and rapid benchmark for a living income in rural areas we therefore focus on the local monetary value a household would need for a 'decent living' to meet the basic human rights, 
irrespective of its physical form (food, labour or money). As such, it indicates the minimum amount of money required if a household has to buy all of their food, finance housing, education and health care at the local market. The actual pattern of expenditures of households is not addressed here, as it is not part of the benchmark, but the benchmark serves as a basis for comparison of households or regions. It can be used in regional development schemes both by policy makers and researchers to provide context for their plans.

Despite the lack of agreement and the many methodological issues, and given the urgency to address poverty and injustice amongst the poor, Anker and Anker (2017b) developed a methodology to calculate a living wage, which is supported by several international NGOs (ISEAL Alliance 2020; Living Income Community of Practice 2020). It is defined as the remuneration for a 'standard work week', necessary for a worker to meet 'his family's basic needs' in a particular place (Anker and Anker 2013c). The Anker Methodology has been used to assess living wages particularly with workers in agricultural commodity supply chains, such as tea plantations in rural Malawi (Anker and Anker 2014b) and flower farms in urban and rural Kenya (Anker and Anker 2014a). Given the debates on living wage and living income and the lack of scientific literature concerning these concepts, we chose to build on the Anker Methodology, which is the most concrete and practical approach currently available. In this paper we focus on our adaptations from the Anker Methodology.

The living wage or living income differs from the poverty lines both conceptually and methodologically. The international poverty line for low-income countries is based on national poverty lines for the 15 poorest economies in the world. Non-food expenditures are generally based on the spending of people who live close to the poverty line and therefore it is questionable if the basic human needs, such as education, housing and health care are really covered. The resulting value of US $\$ 1.90$ per capita per day is subsequently applied to all other lowincome countries in the world. By contrast, the living income benchmark is based on local surveys, so more regionally focused and mainly on rural households, assessing explicitly the non-food costs.

The Anker Methodology (Anker and Anker 2017b) is detailed and, if the guidelines are followed, takes on average about 60 person days for a full study including broad stakeholder engagement (Bhattacharyya 2018). This makes it difficult to deploy quickly as a benchmark for rural developments projects and industries. To explore agricultural development opportunities for smallholder farmers in low-income countries, rapid locally-specific assessments are crucial. Further, regional differences within a country can be very large, e.g. related to access to markets, prices of food and other commodities and family size.

The objectives of our study were to: (1) provide a rapid and incisive method to calculate the living income at local level; (2) develop a set of simple tools for rapid benchmarking of living income; (3) test the method in three case studies in the East African highlands; and (4) compare these three living income estimates with other estimates based on the Anker Methodology.

\section{Methods}

The main differences between living wage and living income is the expression per full time worker (fte) or per nuclear family (Grillo 2018; Anker and Anker 2017b), so the family size is a crucial determinant. Expressing the income in either unit is inadequate when applied to smallholder farming. Both are based on the size of a typical nuclear family for a region. Neither of these allow for the fact that the number of persons in a family can vary widely within a region and therefore the benchmark is not applicable to individual households. The approach is difficult to apply where extended families are predominant. Although Grillo (2018) suggested the benchmark should be adjusted to (extended) household size if contextually necessary, this still does not make it applicable to individual households. For this reason, we propose a way of combining both approaches by expressing the living income on the basis of an adult equivalent (AE). The living income per $\mathrm{AE}$ facilitates calculation of the income for individual households in rural areas, explicitly considering household size. Household composition is often a defining characteristic of different socio-economic groups within a region, which may require different types of support or development interventions.

\subsection{Living income methodology - General framework}

The Living Income Methodology presented here relies on a mixture of methods, triangulating information from household surveys, key informant interviews and secondary reports to assess the annual income required per adult equivalent to afford a decent standard of living. It builds on the Anker Methodology while attempting to improve standardization and simplify the assessment procedures (Online Resource 1). For each issue in which we differ from the Anker Methodology we indicate why and how. 


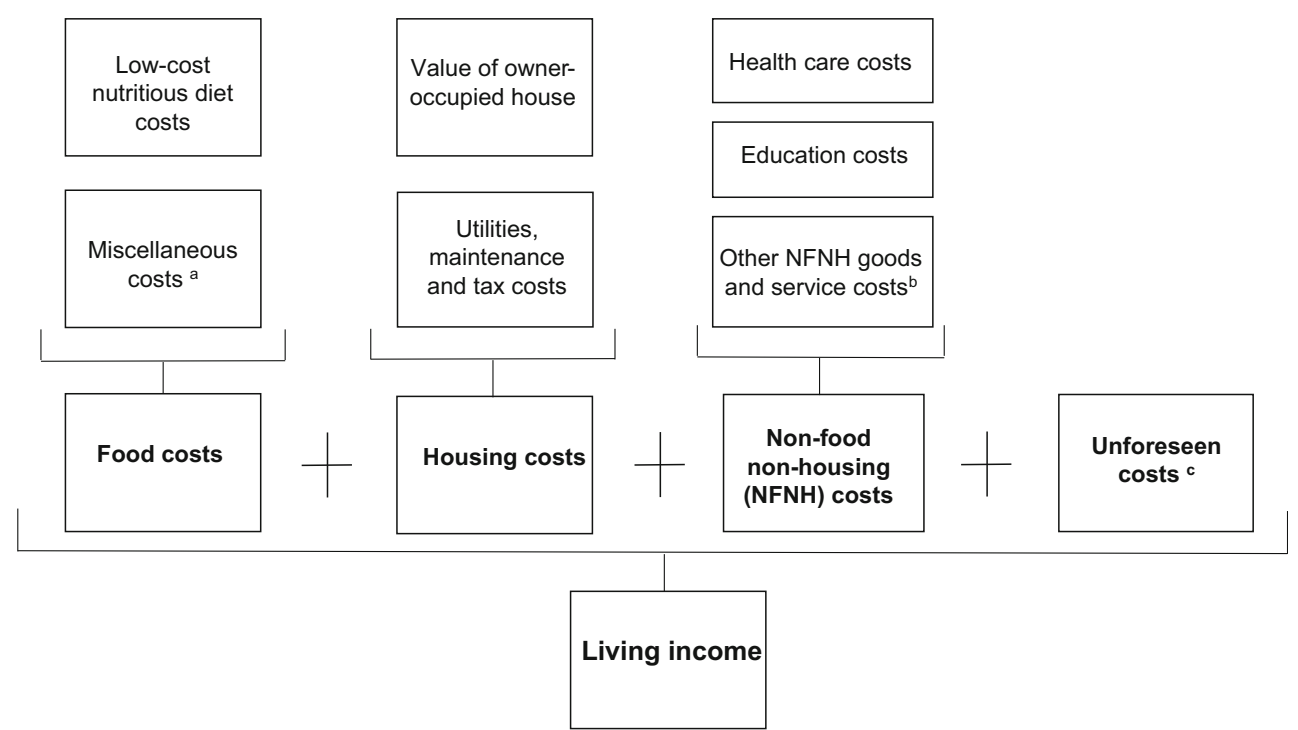

Fig. 1 Overview of cost items included in the Living Income Methodology. ${ }^{\mathrm{a}}$ Miscellaneous costs is $16 \%$ of Low-cost nutritious diet costs (Section 2.4.1); ${ }^{\mathrm{b}}$ Other NFNH goods and services costs is $20 \%$ of total Food, Housing, and NFNH costs (Section 2.4.3); ${ }^{\mathrm{c}}$ Unforeseen costs is $10 \%$ of the Living income (Section 2.5 )
The Living Income Methodology covers four major expenditure groups: food, housing, non-food non-housing (NFNH) and unforeseen costs (Fig. 1). The food costs are the sum of costs for a low-cost nutritious diet plus miscellaneous food costs. The housing costs cover the value of an owner-occupied house plus expenses for utilities, maintenance and taxes. The NFNH costs cover basic health care and education, plus a margin for other NFNH goods and services, such as clothing and footwear, household equipment, transportation and communication. The living income is determined for rural households in a specific area and moment in time, allowing for adjustments for inflation over time (Anker and Anker 2017b). In the next section we explain the components in more detail.

\subsection{Assessing the living income}

A short list of guiding questions to assess living income is presented in Box 1. These questions link to the Living Income Survey, which includes specific local data collection guidelines, and the Living Income Diet Tool, which calculates a low-cost nutritious diet using linear programming. Both are tools to rapidly benchmark the living income in a rural area in a transparent and consistent way. A detailed manual for using the Living Income Diet Tool is available in the supplementary material. A graphical user interface for calculating the Living Income is available at a model portal (https:// models.pps.wur.nl).

Box 1. Ten guiding questions to estimate the living income in a particular time and place

Reference household size and composition (local survey)

1. What is the average number of adult males, adult females and children $(<18$ years old) per rural household?

Food costs (cover a range of markets)

2. What are the two cheapest foods and the one most consumed food for each of the 13 food (sub)groups, available at vendor locations where rural households commonly shop for cheap foods?

3. For these foods: what is the current price (per $\mathrm{kg}$ or $\mathrm{L}$ )?

4. For foods with strongly fluctuating prices within a year ( $>25 \%)$, what is the most common price throughout the year (per $\mathrm{kg}$ or L)?

Housing costs (key informants, focus group discussion, secondary reports)

5. What are the local minimum standards for decent housing for a rural household in relation to the international housing standards?

6. What are the annual housing costs for a house that complies with these local minimum standards for decent housing?

Health care costs (key informant interviews, secondary reports)

7. What are the costs of basic health care insurance; which health care service types are (not) covered?

8. What are the costs of health care services not covered by the basic insurance?

Education costs (key informants, focus group discussion, secondary reports)

9. How many years of education are officially counted for completion of primary and lower secondary school?

10. What are the household out-of-pocket expenses per child for one year of public education at each these education levels?

For more information, see Online Resource 1, and the full Living Income Survey in Online Resource 2 


\subsection{Reference household size and composition}

We build on the living income concept as smallholder agriculture is mostly a family business. The local average household size and composition of male and female adults, and children ( $<18$ years old) is referred to as the reference household. This size and composition can be determined using own survey data or secondary data, for example from local household surveys or a recent national demographic survey. Preferably, regionspecific data are used, as household composition can vary between urban and rural areas and between regions. The Anker Methodology refers to the nuclear family if possible (Anker and Anker 2017b). We follow the approach to include extended family members for societies where this is relevant. In regions such as north Ghana with 10-14 people per household (De Jager et al. 2017) and southern Mali with 8-45 household members (Falconnier et al. 2015) the nuclear family does not reflect reality sufficiently. Depending on the variation the average or median household size is determined. For the living wage also the number of full time labourers is required, which is generally based on statistics on labour force participation rates, unemployment rates and age. It is set to a value between one and two persons per family (Anker and Anker 2017a). We do not follow the limit of the Anker Methodology to a minimum of four and a maximum of six members per reference household, nor for the number of full time labourers between one and two per reference household.

To assess the role of agriculture in rural development and food security in low-income countries the living income per adult equivalent (AE) seems the most appropriate benchmark to reflect the potential aspirations of rural families. Here we deviate from the Anker Methodology, based on national statistics on labour participation (Anker and Anker 2017b), as we prefer a flexible benchmark that can be used for individual households, irrespective of their size.

Our assessment is split in two parts, i) food costs expressed per Adult Male Equivalent (AME) and subsequently converted to Adult Equivalent (AE) per household, and ii) other costs expressed directly per AE. In an AME, men, women and children are included, according to their energy needs. One AME requires $2500 \mathrm{kcal}$ per person per day, which is the accepted international standard for manual work in agriculture (FAO/WHO/UNU 2001), the common situation in rural areas in low-income countries. Females are equivalent to $0.82 \mathrm{AME}$ and children ( $0-18$ years) to $0.75 \mathrm{AME}(\mathrm{FAO} / \mathrm{WHO} / \mathrm{UNU}$ 2001). Old people are included as adults according to their sex, as not all surveys include separate age classes for elderly. In the $\mathrm{AE}$, the first adult in a household is assigned value of 1.0 , all additional adults a value of 0.7 and children a value of 0.5 , accounting for economies of scale in the needs of household members, e.g. for housing (OECD 2011; Atkinson et al. 1995). We took the "Oxford" scale, as the modified OECD scale is based on the situation in OECD countries. We assume that in low-income countries the equivalence elasticity is less than in high-income countries. This approach allows to easily calculate the living income related to food security for households of different size based on their composition, including extended families. From the survey the average household composition is calculated and converted to $\mathrm{AME}$ and $\mathrm{AE}$ by using the equivalence factors. Subsequently, all calculated variables are expressed per AE. This value can then be used to calculated the living income for an individual household, based on household composition.

\subsection{Methods for cost calculation}

\subsubsection{Food costs}

The Anker Methodology starts from a preliminary model diet, based on current diets, a poverty line-related diet or a diet proposed by a nutritionist and is adapted stepwise to meet WHO standards for a nutritious diet. Two excel sheets were developed to calculate i) the household energy needs based on age, sex, body size and physical activity and ii) a low cost diet in an iterative procedure, going from current or expensive (nutritionist diet) to low cost, covering 20 foods and 11 food groups (Anker and Anker 2017b).

We take the position that the living income covers the lowest cost nutritious diet, irrespective of the current diet. Based on the Woman Dietary Diversity Score (WDDS; Kennedy et al. 2010) which ensures sufficient food options for a nutritious and micronutrient-sensitive diet, we distinguish nine food groups: starchy staples, vegetables, fruits, meat, fish and seafood, eggs, milk and milk products, legumes nuts and seeds, and fats and oils, some of which are subdivided. Online Resource 1 gives the details on the food subgroups and the foods covered.

First, a selection of cheap and commonly-consumed foods is identified within each food group from the available foods at multiple local vendors, such as open-air markets and small village shops, specifically the places where the poor buy their foods. To ensure sufficient options for a low-cost nutritious diet, prices are collected for at least three foods of acceptable quality per food (sub)group, free of mycotoxins. Two of them are the cheapest (per kg or L) and one is the most commonly consumed food (Online Resource 2). For all selected foods, current prices (at the moment of collection) are collected from 5 to 10 different vendor locations, depending on the price variability. In case of strong fluctuations throughout the year (>25\%) the most common prices (throughout the year) are also collected from the same vendor locations and used in the calculations. Starchy staples, vegetables and fruits are most likely to require such a price correction, due to their seasonal availability. For both the current and the most common price, the median price is used in our calculations.

Next, the Living Income Diet Tool is used to calculate the lowest-cost diet per AME, The Living Income Diet Tool is an 
Table 1 Nutritive requirements in the Living Income Diet Tool

\begin{tabular}{|c|c|c|c|}
\hline Dietary components & Required intake per AME & Unit & Source \\
\hline Energy $^{a}$ & $2500(2400-2600)^{b}$ & $\mathrm{kcal} /$ day & (FAO/WHO/UNU 2001) \\
\hline Carbohydrate $^{\text {a }}$ & $\geq 344$ & g/day & (WHO/FAO 2003) \\
\hline Protein $^{\mathrm{a}}$ & $\geq 63$ & g/day & (WHO/FAO 2003) \\
\hline Total lipid (fat) ${ }^{a}$ & $\geq 42$ & g/day & (WHO/FAO 2003) \\
\hline Calcium, $\mathrm{Ca}$ & $\geq 833$ & $\mathrm{mg} /$ day & (WHO/FAO 2004) \\
\hline Iron, $\mathrm{Fe}$ & $\geq 36$ & $\mathrm{mg} /$ day & (IOM 2001) \\
\hline Zinc, Zn & $\geq 15$ & $\mathrm{mg} /$ day & (Hotz and Brown 2004) \\
\hline Vitamin $A^{c}$ & $\geq 99$ & IU/day & (WHO/FAO 2004) \\
\hline Vitamin $\mathrm{C}$, total ascorbic acid & $\geq 43$ & $\mathrm{mg} /$ day & (WHO/FAO 2004) \\
\hline Folate, DFE & $\geq 320$ & $\mu \mathrm{g} /$ day & (WHO/FAO 2004) \\
\hline Thiamine & $\geq 1.0$ & $\mathrm{mg} /$ day & (WHO/FAO 2004) \\
\hline Riboflavin & $\geq 1.1$ & $\mathrm{mg} /$ day & (WHO/FAO 2004) \\
\hline Vitamin B12 & $\geq 2.0$ & $\mu \mathrm{g} /$ day & (WHO/FAO 2004) \\
\hline
\end{tabular}

The required daily intake of the dietary components is the minimum intake that poses no risk or adverse health effects to people between 19 and 50 years of age

${ }^{\mathrm{a}}$ Energy originates for at least $55 \%$ from carbohydrates $(4 \mathrm{kcal} / \mathrm{g} ; 2500 \times 0.55 / 4=344 \mathrm{~g} /$ day carbohydrates $), 10 \%$ from protein $(4 \mathrm{kcal} / \mathrm{g} ; 2500 \times 0.10) /$

$4=63 \mathrm{~g} /$ day protein), $15 \%$ from fat $(9 \mathrm{kcal} / \mathrm{g} ; 2500 \times 0.15) / 9=42 \mathrm{~g} /$ day fat $)(\mathrm{WHO} / \mathrm{FAO} 2003)$

${ }^{\mathrm{b}}$ Constraint in Living income Diet Tool to ensure sufficient flexibility to compose diets

${ }^{\mathrm{c}}$ IU: International unit, depending on the type of vitamin A

optimization model and described in detail in Online Resource 3. It ensures that meeting all dietary requirements for energy, carbohydrates, protein, fat, and a selection of micronutrients, based on the most common deficiencies in low-income countries (Beal et al. 2017; Table 1) are met. It covers food waste, common cooking practices and retention factors. The model behaves as expected and intended (Online Resource 3). We assume that by covering these nutrients other essential nutrients are also covered. Dietary requirements are such that both females and males cover their minimum requirements, e.g. the threshold for iron is adequate for women and consequently slightly higher than strictly needed for males. We assume that foods are distributed among household members according to their needs. The calculated diet is an intermediate product, solely for the purpose of cost assessment. We do not evaluate the diet itself.

Nutrient contents of foods are based on the nutrient composition of the raw purchased product, the average waste factor of its food group (USDA 2018; Gustavsson et al. 2011; FAO 2018) and the average retention factor per nutrient after preparation (e.g. boiling, frying) specified for the food group (Online Resource 3) based on USDA (2007).

In addition to the calculated lowest cost, $4 \%$ is added to cover food waste, based on $5 \%$ waste of fresh foods and $1 \%$ waste of processed foods in the consumption phase for Sub Saharan Africa (Gustavsson et al. 2011). A small amount of additions like salt, spices and condiments are required to make a meal palatable. Similar to Anker and Anker (2017b) we set this at $2 \%$. Home-produced foods are valued against market prices. The minimum cost diet covering the nutritional requirements, as calculated with the Living Income Diet Tool, contains a limited set of foods, does not consider portion size as a limit to the consumption a single food, and it assumes people eat this same diet every day. In reality people buy and consume more different foods. To allow some variation in the diet for matters of palatability and portion size, another $10 \%$ was added to the food costs. This is similar to the value used by Anker and Anker (2017b).

\subsubsection{Housing cost}

Whilst the cost of 'shelter' is included in the international poverty line, what constitutes acceptable shelter is unclear. To estimate a cost for the Living Income Methodology we follow the local minimum standard for basic healthy housing which is based on international standards for healthy housing adjusted to local conditions, such as material availability, climate, and the reference household size and composition. The housing construction should be able to sustain about 50 years without major repairs - also called the 'expected service life' of the house (Anker and Anker 2017b). Estimation of housing costs involves: 1) defining a local standard for basic healthy housing for a reference household, and 2) estimating the annual costs of a house that meets these standards. While the Anker Methodology is based on secondary data, we use a combination of secondary reports, local observations, key informant interviews and/or focus group discussions. The expected service life of a house needs to be locally checked, as from our experience 50 years is unrealistically long for some rural areas in East Africa, depending on the building materials used. This is then included in the calculations. 
The required number of interviews depends on the variation in costs estimates. Based on our experience in the field in East Africa we recommend to include ten if possible, but at least five informants. Information should be collected on 1) total costs of constructing the house including all materials and labour and the expected service life, 2) annual utility costs, including water, electricity, cooking fuel, heat, and lighting, 3) annual costs for routine maintenance and repairs, and 4) annual costs for taxes, levies, fees and house insurance. When unclear, costs for routine maintenance and repairs can be set at $0.3 \%$ of total construction costs, which is the average in our case studies (see Results). Construction costs are divided over the expected service life.

\subsubsection{Non-food non-housing costs}

Non-food non-housing costs (NFNH) cover costs for education, health and other basic needs, such as clothing and footwear, transport, communication. The Anker Methodology calculates the NFNH from secondary data on the ratio of NFNH:food costs multiplied by the costs of the living wage model diet. Subsequently, it checks if the calculated NFNH cost cover the health care and education costs based on a rapid assessment using local primary and secondary data. Food, housing, health care and education costs should typically be below 60-70\% of all spendings (Anker and Anker 2017b). In our methodology we assess health care and education costs similarly to the rapid assessment in the Anker Methodology. However, we calculate 'Other NFNH goods and services' as a margin of $20 \%$ of total Food, Housing and NFNH budget (Online Resource 1). Although our costs for health and education also rely partly on current spending, we do not include current spending ratios in our search for a living income.

Health care costs Costs of health care include all annual household out-of-pocket expenses to cover basic health care based on the locally available services. If basic health insurance is available, this may be the best option, but coverage should be checked. If insurance is not available, or only partly, an extra assessment is needed to estimate expenses for health care not covered by insurance. We assess each identified local health care service. Costs are estimated per household per year based on the average usage and the average costs per treatment for the three most common diseases in the study area, as the most common diseases have the largest impact on health in terms of people affected and are relatively easy to cure (Online Resource 1). A combination of secondary reports (e.g. demographic health surveys, local health care facility, patient records, etc.) and key informant interviews (e.g. staff in local clinics, health care extension officers) can be used as source of information. The required number of informants depends on local circumstances, but a minimum of three cross-checks per cost item is recommended.
Education costs Education costs include all annual householdout-of-pocket expenses to cover decent public primary and lower secondary education for all children in the reference household. In most countries education is compulsory starting at the age of 5 to 7 until the age of 11 to 18 years, roughly covering primary and lower secondary school (UNESCO 2000). Primary education is not always free, despite Article 26 of the International Declaration of Human Rights. We assumed that public schools provide education of sufficient quality. Information on costs is ideally gathered from secondary data and key informant interviews and/or focus group discussions with e.g. local education experts and parents/caretakers of school children. Such informants and secondary data may be more reliable than teachers or government officials. We suggest to include at least ten informants, but more can be interviewed depending on the variation among sources. Household out-ofpocket expenses cover only parental responsibilities for essential needs for a child to go to school (school fees, clothing/ uniform, materials such as books). The list of 'essential needs' can be deduced from cost items reported by the majority of informants, or consensus within a focus group. Costs for school lunches are included in the food costs. The total education costs per child are assessed and divided over 18 years, giving the average annual education costs per child.

\subsection{Total budget for living income}

The total living income includes the sum of estimated costs for food, housing and NFNH per reference household, plus a margin for Unforeseen Events estimated at $10 \%$ of the total living income budget. An excel file is available to combine the survey and diet data into the living income (Online Resource 4).

To be able to compare the living income and its components across countries the local units are converted to Purchasing Power Parity to the international (US) dollar (US\$ PPP). The PPP conversion factor is the equivalent local currency required to buy goods and services in the domestic market equivalent to what a US dollar would buy in the United States. The PPP covers a correction for relative price developments and exchange rates (World Bank 2015b). We use the US\$ PPP for individual household consumption expenditure (US\$ PPP-IHC), which is also the basis for the World Banks's international poverty threshold of US\$ 1.90 per capita per day (World Bank 2015b). It covers the same items that we distinguished in our framework (Fig. 1). The only exception is for NFNH costs, where we do not consider recreation, restaurants, alcoholic beverages, tobacco and narcotics as belonging to basic needs, and the PPP-IHC does (World Bank 2015b). However, Dikhanov et al. (2017) reported that the influence of leaving out non-poverty items and the selection of poverty specific goods, as we do in our procedure to select the cheapest food items from each food group, has a negligible effect on the PPP value. 
PPP values change over time and for each country we used the PPP values for the year the prices were reported and converted them to 2017, based on inflation rates and the consumer price indices as reported by the World Bank following their calculation procedure (World Bank 2018a).

\subsection{Case studies: Lushoto District, Tanzania; Isingiro, Uganda and Sidama, Ethiopia}

All three countries of our cases, i.e. Ethiopia, Tanzania and Uganda, are classified as low-income countries and were part of the 15 countries included in the assessment of the extreme poverty line of US \$ 1.90 in 2011 (Chen and Ravallion 2010; World Bank 2015b).

\subsubsection{Tanzania}

The United Republic of Tanzania has over 57 million inhabitants, $67 \%$ of which live in rural areas (World Bank 2018a). General development trends in Tanzania include population growth, urbanization, and economic growth of $7 \%$ annual GDP gains since 2010, and decreases in extreme poverty. Despite these positive trends, Tanzania remains a low income country and poverty is widespread. Half of the population lives of less than US\$1.90 a day and 93\% lives on less than US\$5.50 a day, both in US\$ 2011 PPP (World Bank 2014). The majority of the households facing poverty lives in rural areas. The national poverty line was US\$ PPP 1.47 per adult equivalent per day $^{1}$ in 2011, excluding budget for housing and clothing national (National Bureau of Statistics Tanzania 2015).

The living income for rural households in Lushoto District, in the West Usambara Mountains of Tanga region, northern Tanzania, was estimated based on secondary data and primary data collected through key informant interviews in Lushoto (district capital) and the villages Kongei, Migambo and Mshizii. Food price data was collected in May 2018, and all other data was collected in October 2017.

\subsubsection{Uganda}

The republic of Uganda has over 43 million inhabitants (United Nations et al. 2017), $80 \%$ of whom live in rural areas (Uganda Bureau of Statistics 2014). Uganda is among the countries with the highest growth in GDP among countries in SSA world (World Bank 2016). The share of the population living below the poverty line decreased from $31 \%$ in 2006 to $20 \%$ in 2013. Absolute numbers living in poverty, however, increased due to the rapid population growth (Uganda Bureau of Statistics 2016). Poverty in Uganda differs among regions and is more severe in rural than in urban areas. Most of the poor live in the Northern, Eastern and Western regions, whereas the Central

\footnotetext{
${ }^{1}$ TZS 23,933 per 28 days, with prices from Oct. 2010 to Sept. 2011;
}

region, including the capital Kampala, is relatively better off world (World Bank 2016). The national poverty line was US\$ 1.46 (2011 PPP) in 2012 (Jolliffe and Prydz 2016).

The living income for rural households in Isingiro District, in the Western region of Uganda, was estimated based on secondary data and primary data collected through key informant interviews in Birere and Kaberebere sub-counties. Food price data was collected in village shops and at the local market in the rural town of Kaberebere. All data was collected in August 2018.

\subsubsection{Ethiopia}

Ethiopia had a population of 105 million people in 2017 (World Bank 2018b). Ethiopia is characterized by an average GDP growth rate of $11 \%$ over the last decade, which is about double of the average growth for Sub Saharan Africa (UNDP 2014). Despite this two-digit GDP growth, $27 \%$ of the population lives below the international poverty line of US\$ 1.90 per day. The national poverty line was US\$ 1.80 (2011 PPP; Jolliffe and Prydz 2016). Although agriculture has been the back bone of Ethiopian economy, the increasing rural population and resulting farmland fragmentation put huge pressure on meeting food requirements of both urban and rural population, which has huge implications on the affordability of foods for the poor (Mellisse et al. 2017).

The population density in rural Wondo Genet and Melga districts in Sidama zone in southern Ethiopia exceeds 1000 person per $\mathrm{km}^{2}$ and the average farm size per household is less than 1 ha (Mellisse et al. 2017). The data for assessing the living income for rural households were based on secondary and primary sources collected through key informant interviews in Wondo Genet and Melga districts. Food price data were collected from several vendor locations in July 2018 in Tula and Wugigra, capital towns of Wondo Genet and Melga districts, respectively.

\section{Results}

\subsection{Reference household size and composition}

Reference household (RH) size and composition in Lushoto District were obtained from the Rural Household Multiple Indicator Survey database (RHoMIS) for 2015 (Hammond et al. 2017). For Isingiro District, Uganda, they were obtained from the Banana Agronomy Baseline Survey among 92 farm households in the region (Banana Agronomy Baseline Survey, NARO-IITA Uganda, unpubl.) and for Sidama they were obtained from a survey of 120 farm households (Mellisse et al. 2017; Table 2). All of these surveys were based on random sampling of rural households in their study areas and were taken from project baseline studies. The living income calculated from this data refers to the sampled districts only and are hence local/regional living income. Reference 
Table 2 Reference household (RH) composition for Lushoto District, Tanzania, Isingiro District, Uganda, and north east Sidama Zone, Ethiopia

\begin{tabular}{llll}
\hline Age \& gender group & \multicolumn{2}{l}{ number/RH } & \\
\cline { 2 - 4 } & Lushoto & Isingiro & Sidama \\
\hline Adults, male & 1 & 1.5 & 2.2 \\
Adults, female & 1 & 1.5 & 1.7 \\
Children $(<18)$ & 3 & 2.6 & 4.3 \\
AME & 4.1 & 4.7 & 6.8 \\
AE & 3.2 & 3.7 & 5.2 \\
\hline
\end{tabular}

$A M E$ adult male equivalent, $A E$ adult equivalent

household sizes were 3.2 AE in Lushoto, 3.7 AE in Isingiro and 5.2 AE in Sidama.

\subsection{Costs per item of the living income}

\subsubsection{Diet composition and food costs}

Food prices for Lushoto District were collected in May 2018 at multiple vendor locations, covering central open air markets and small shops in Lushoto (district capital), Migambo and Mshizii (villages; Table 3). Both the current costs and the most common prices are collected (for details see Online resources 2). The most common prices throughout the year were used for tomato, carrot, cabbage, avocado, banana, chicken eggs, duck eggs, cocoyam, because their current price differed $>25 \%(-50 \%$ to $+67 \%)$ from the most common price throughout the year. Nutrient contents of Gallant soldier (Galinsoga parviflora), which was lacking in the USDA Food Composition database, were taken from Wehmeyer and Rose (1983). Results of the Living Income Diet Tool show that the minimum costs for a nutritious diet were 1.29 US\$ PPP/AME/ day or 1920 US\$ PPP/RH/year.

Food prices for Isingiro District were collected in June 2018 at multiple vendor locations, covering stands at the central market and small shops in Kaberebere town, and small shops in Birere. A price correction was made for carrots, cabbage, papaya, sweet banana, dried tilapia, groundnut (flour), peas, and ghee. Nutrient composition of 'small dried fish' called Silver cyprinid (Rastrineobola argentea; also Lake Victoria sardine or mukene,) was lacking for Uganda and was obtained from the Tanzania food composition tables (item 313, Lukmanji et al. 2008). Results of the Living Income Diet Tool show that minimum costs for a nutritious diet were US\$ 1.11 PPP/AME/day or US\$ 1900 PPP/RH/year (Table 3).

Food prices for Sidama were collected in July 2018 at multiple vendor locations, covering markets and small shops in the villages Tula, Yirgalem and Wugigra. Price corrections were made for kocho, maize, kale, lettuce, tomato, carrot, onion, chili pepper, papaya, mango, orange, sheep meat, haricot bean and faba bean. Kocho is the processed corm of enset (Ensete ventricosum) and is a typical Ethiopian staple food. Nutrient composition of kocho was obtained from Ethiopian Food Composition Table part IV (FAO and Ethiopian Health and Nutrition Research Institute 1995). The Living Income Diet Tool showed that the minimum costs for a nutritious diet were US\$ $1.19 \mathrm{PPP} / \mathrm{AME} /$ day or US\$ $2985 \mathrm{PPP} / \mathrm{RH} /$ year (Table 3).

\subsubsection{Housing costs}

Local minimum standards for decent housing in Lushoto District, Tanzania, were compiled based on discussions with four local agricultural extension officers, six resource-poor household heads, and observations of the research team. A Lushoto reference family requires a living space of at least $30 \mathrm{~m}^{2}$ with one living room and at least two bedrooms (Table 4). The toilet/bathroom and kitchen may be outside the housing unit. Housing costs were based on information from five owners of houses slightly above the local minimum standards for decent housing (three resource-rich farmers, one village school teacher, and one village doctor) and from ten owners of houses below the local minimum standard. Estimated annual housing costs for a reference family in Lushoto are US\$ PPP 1170, including construction costs (US\$ PPP 18,000 over 50 years), plus routine maintenance and repair costs and utility costs (Table 5). Taxes, levies and house insurance costs were not common in Lushoto District. Local minimum standards and costs for decent housing in Isingiro District, Uganda, are assessed in a comparable manner and resulted in similar estimated annual costs of US\$ PPP 1147 (Table 4). In Sidama zone, Ethiopia, two focus group discussions were organized with six people in Wondo Genet and five in Melga. The expected service life of housing without major investments in repairs was about 30 years instead of 50. Hence, in our calculations we increased the reported construction costs by $25 \%$ to cover the extra maintenance. Total annual housing costs were estimated at US\$ PPP 1541 (Table 5).

\subsubsection{Health care}

The health care system in Lushoto District, Tanzania includes public facilities (dispensaries) in most villages and private facilities (missionary) in some villages. Key informant interviews were held with six health care workers from two dispensaries and one missionary health care facility, and with one pharmacist. Basic health care insurance is available for all villagers through the Community Health Fund (CHF). The membership covers all public health care costs for six household members, including doctor consultation and complete treatment with medicine and laboratory tests for all common diseases. The interviewees reported that this does not cover all household expenses on health care, as medicines are regularly 
Table 3 Composition and costs for a low-cost nutritious diet calculated with the Living Income Diet Tool for the three case study regions based on local market prices per adult male equivalent (AME) per day

\begin{tabular}{|c|c|c|c|c|}
\hline Food (sub)group & Food & Market price & $\begin{array}{l}\text { Calculated amount purchased } \\
\text { g/AME/day }\end{array}$ & $\begin{array}{l}\text { Calculated food costs } 2017 \\
\text { US\$ PPP/AME/day }\end{array}$ \\
\hline \multicolumn{2}{|l|}{ Lushoto District, Tanzania } & \multicolumn{3}{|c|}{ April ' 18 in TZS/kg } \\
\hline Starchy staple & Maize, whole grain flour & 800 & 445 & 0.43 \\
\hline Dark green leafy vegetables & Gallant soldier $^{\text {a }}$ & 833 & 420 & 0.42 \\
\hline Dark green leafy vegetables & Cabbage & 313 & 71 & 0.03 \\
\hline Legumes, nuts and seeds & Beans, common & 2400 & 30 & 0.08 \\
\hline Legumes, nuts and seeds & Groundnut & 2500 & 27 & 0.08 \\
\hline Fats and oils & Palm oil ${ }^{\mathrm{b}}$ & 3804 & 7 & 0.03 \\
\hline Organ meat & Liver, cow & 7750 & 5 & 0.04 \\
\hline \multicolumn{4}{|l|}{ Low-cost nutritious diet } & 1.11 \\
\hline \multicolumn{4}{|c|}{ Miscellaneous food costs ( $16 \%$ of low-cost nutritious diet costs) } & 0.18 \\
\hline \multicolumn{4}{|c|}{ Total food costs (US\$ PPP/AME/day) } & 1.29 \\
\hline \multicolumn{2}{|l|}{ Isingiro District, Uganda } & \multicolumn{3}{|c|}{ June ' 18 in $\mathrm{UGX} / \mathrm{kg}$} \\
\hline Legumes, nuts and seeds & Beans, common & 1550 & 431 & 0.51 \\
\hline Starchy staples & Maize, white flour & 1500 & 168 & 0.19 \\
\hline Dark green leafy vegetables & Amaranth leaves & 1500 & 32 & 0.04 \\
\hline Other fruits & Avocado & 1200 & 196 & 0.18 \\
\hline Fish and seafood & Small silver fish, dried ${ }^{\mathrm{c}}$ & 4000 & 10 & 0.03 \\
\hline Organ meat & Liver, cow & 6000 & 2 & 0.01 \\
\hline \multicolumn{4}{|l|}{ Low-cost nutritious diet } & 0.96 \\
\hline \multicolumn{4}{|c|}{ Miscellaneous food costs ( $16 \%$ of low-cost nutritious diet costs) } & 0.16 \\
\hline \multicolumn{4}{|c|}{ Total food costs (US\$ PPP/AME/day) } & 1.11 \\
\hline \multicolumn{2}{|l|}{ Sidama zone, Ethiopia } & \multicolumn{3}{|c|}{ July ' 18 in birr $/ \mathrm{kg}$} \\
\hline Starchy staple & Maize grain & 7 & 219 & 0.13 \\
\hline Starchy staple & Kocho $^{\mathrm{d}}$ & 7 & 257 & 0.14 \\
\hline Legumes nuts and seeds & Haricot beans & 10 & 296 & 0.26 \\
\hline Organ meat & Liver and kidney & 58 & 21 & 0.11 \\
\hline Dark green leafy vegetable & Kale & 16 & 104 & 0.14 \\
\hline Fats and oils & Soyabean oil & 72 & 25 & 0.16 \\
\hline \multicolumn{4}{|l|}{ Low-cost nutritious diet } & 0.93 \\
\hline \multicolumn{4}{|c|}{ Miscellaneous food costs (16\% of low-cost nutritious diet costs) } & 0.15 \\
\hline \multicolumn{4}{|c|}{ Total food costs (US\$ PPP/AME/day) } & 1.08 \\
\hline
\end{tabular}

Lushoto District, Tanzania US\$ 1 PPP = 835 TZS for 2017; Isingiro District, Uganda US\$ 1 PPP = 1243 UGX for 2017; Sidama Zone, Ethiopia US\$ 1 PPP $=9.33$ birr in 2017 (World Bank 2018a)

${ }^{\mathrm{a}}$ Galinsoga parviflora; ${ }^{\mathrm{b}}$ Fortified with $2 \mathrm{~g} / 100 \mathrm{~g}$ vitamin $\mathrm{A} ;{ }^{\mathrm{c}}$ Silver cyprinid (Rastrineobola argentea) ${ }^{\mathrm{d}}$ the corm of enset

out of stock and have to be purchased privately. Total health care costs added up to US\$ $48 \mathrm{PPP} / \mathrm{RH} /$ year (Table 6).

Basic health care insurance was not available in rural Uganda. Key informant interviews were performed with health care workers at three public health care centres at sub-county level, and at pharmacies. The three most important health care service types were: (i) doctor consultation at a public health care centre, (ii) medicine from a pharmacy, and (iii) laboratory self-test for malaria. The three most common diseases in this area as reported in patient records of the local health care centre were: malaria, urinary tract infection (UTI), and cough/flu. Altogether, health care costs in Isingiro District were estimated at US\$ $131 \mathrm{PPP} / \mathrm{RH} /$ year (Table 6).

Basic health care in Ethiopia was obtained from two public clinics. The main health costs of a household related to medicines. The three most common diseases treated were typhoid fever, diarrheal diseases and malaria. Medicines from a public pharmacy cost US\$ 89 PPP/RH/year (Table 6). 
Table 4 Overview of local minimum standards for decent housing for the reference household in rural areas of Lushoto District, Tanzania, Isingiro District, Uganda, and Sidama zone, Ethiopia

\begin{tabular}{|c|c|c|c|c|}
\hline \multicolumn{2}{|c|}{ International minimum standard for decent housing } & \multicolumn{3}{|l|}{ Local minimum standard } \\
\hline Principle & Specification & $\begin{array}{l}\text { Lushoto District, } \\
\text { Tanzania }\end{array}$ & $\begin{array}{l}\text { Isingiro District, } \\
\text { Uganda }\end{array}$ & $\begin{array}{l}\text { Sidama Zone, } \\
\text { Ethiopia }\end{array}$ \\
\hline \multicolumn{5}{|c|}{ Acceptable construction materials for walls, roof and floor } \\
\hline $\begin{array}{l}\text { Walls from durable } \\
\text { material without } \\
\text { leaks }\end{array}$ & Well-joined bricks or cement & $\ldots$ or baked bricks + mud & $\begin{array}{l}\ldots \text { or stones }+ \\
\text { cement }\end{array}$ & $\begin{array}{l}\ldots \text { or timber } \\
\text { (Juniperus) + mud } \\
\quad+\text { cement }\end{array}$ \\
\hline $\begin{array}{l}\text { Roof from durable } \\
\text { material without } \\
\text { leaks }\end{array}$ & Cement, tile, or zinc/iron sheets & & $\begin{array}{l}\ldots \text { or cured timber }+ \\
\text { corrugated iron }\end{array}$ & ... or corrugated iron \\
\hline $\begin{array}{l}\text { Floor from durable } \\
\text { material without } \\
\text { leaks }\end{array}$ & Cement, stone, tile or wood; can't be mud or dung & & & cement \\
\hline \multicolumn{5}{|c|}{ Acceptable amenities such as toilet and, water } \\
\hline $\begin{array}{l}\text { Safe sanitation (toilet } \\
\text { and sewage disposal) }\end{array}$ & $\begin{array}{l}\text { Flush toilet, pit latrine with slab, or VIP toilet; in } \\
\text { or near the house; shared by }<15 \text { people }\end{array}$ & & & \\
\hline $\begin{array}{l}\text { Safe drinking water } \\
\text { not far from home }\end{array}$ & $\begin{array}{l}\text { Piped into house/yard, pump, public tap, } \\
\text { protected well, or bore hole }\end{array}$ & & & \\
\hline \multicolumn{5}{|c|}{ Acceptable ventilation, lighting and temperature } \\
\hline $\begin{array}{l}\text { Good ventilation } \\
\text { quality }\end{array}$ & $\begin{array}{l}\geq 1 \text { window per room; extra ventilation when } \\
\text { cooking indoors }\end{array}$ & $\begin{array}{l}\text { Chimney or extra window } \\
\text { when cooking indoors }\end{array}$ & & \\
\hline Adequate lighting & $>1$ window per room or another light source & $\begin{array}{l}\text { Light source: electricity } \\
\text { solar, or kerosene }\end{array}$ & $\begin{array}{l}\text { Light source: } \\
\text { kerosene or solar }\end{array}$ & \\
\hline $\begin{array}{l}\text { Comfortable ambient } \\
\text { temperature }\end{array}$ & $\begin{array}{l}\text { Indoor heating or air conditioning in areas with } \\
\text { extreme temperatures }\end{array}$ & $\begin{array}{l}\text { Not necessary for climate } \\
\text { conditions }\end{array}$ & $\begin{array}{l}\text { Ventilator in each } \\
\text { room }\end{array}$ & \\
\hline \multicolumn{5}{|l|}{ Acceptable living space } \\
\hline Sufficient living space & $\begin{array}{l}30-36 \mathrm{~m}^{2} \text { in low income country; } 36-60 \mathrm{~m}^{2} \text { in } \\
\text { middle income country; Ceiling } \geq 2 \mathrm{~m}\end{array}$ & $\begin{array}{l}30 \mathrm{~m}^{2} \text { excl. toilet and } \\
\text { kitchen (may be outside) }\end{array}$ & $16 \mathrm{~m}^{2}$ & $30 \mathrm{~m}^{2}$ excl. toilet \\
\hline Sufficient bedrooms & Max. 2-3 persons per bedroom & 2 bedrooms/RH & 3 bedrooms/RH & 4 bedrooms/RH \\
\hline \multicolumn{5}{|c|}{ Acceptable house condition and environment } \\
\hline $\begin{array}{l}\text { Proper house } \\
\text { condition }\end{array}$ & House in good state of repair and good foundation & & & \\
\hline $\begin{array}{l}\text { Safe outside } \\
\text { environment }\end{array}$ & No risk of landslides, floods, pollution, etc. & & & \\
\hline $\begin{array}{l}\text { Separation from } \\
\text { production }\end{array}$ & Animal housing outside the house & & & \\
\hline
\end{tabular}

The local minimum standard complies with international minimum standards, and is adjusted where needed to local conditions

\subsubsection{Education}

The Tanzanian education system includes seven years of primary education (ages 7-13) and 4 years of secondary education (ages 14-17). Key informant interviews were performed with parents of children in public primary school $(n=13)$, and lower secondary school $(n=10)$ The household out-of-pocket expenses per child per year were reported. Essential items reported most frequently by informants $(n \geq 5)$ as parental responsibility were: uniform, shoes and a schoolbag (category Clothing), books and supplies (category Materials), school maintenance fee, exam fee and security fee (category Fees).
The total education costs were US\$ 1580 PPP per child or US\$ 260 PPP/RH/year (Table 7).

The Ugandan education system also includes seven years of primary and four years of secondary education. Cost items were estimated through focus group discussion with parents/ caretakers of school-going children $(n=10)$. Estimated annual education costs in Isingiro District are US\$ 510 PPP/RH/year (Table 7).

In Ethiopia primary school takes six years and secondary school four years and no school fees are paid. The costs were estimated in a focus group discussion with parents and amounted to US\$ $310 \mathrm{PPP} / \mathrm{RH} / \mathrm{year}$ (Table 7). 
Table 5 Overview of estimated housing costs for a house complying with local minimum standards for decent housing for a reference household in rural areas of Lushoto District, Tanzania, Isingiro, Uganda and Sidama Zone, Ethiopia, for 2017

\begin{tabular}{llll}
\hline Cost item & Lushoto District, Tanzania & Isingiro District, Uganda & Sidama zone, Ethiopia \\
\hline & US\$ PPP/RH/year & & 1387 \\
Construction costs & 359 & 387 & 62 \\
Routine maintenance and repairs & 90 & 63 & 0 \\
Taxes, levies, fees and house insurance & 0 & 0 & 93 \\
Utilities (water, electricity, cooking fuel) & 719 & 714 & 1174 \\
Total housing costs & 1168 & & 0.85 \\
Total housing costs & US\$ PPP/AE/day & 0.81
\end{tabular}

$R H$ Reference household, $A E$ Adult equivalent

\subsection{Living income}

Based on the previously presented data the living income expressed in US\$ PPP per adult equivalent per day is estimated at 4.04 in rural Lushoto District, Tanzania 3.82 in Isingiro district, Uganda and 3.60 in Sidama Zone, Ethiopia (Table 8). The living income and the share of the different cost items for the districts in Tanzania and Uganda are quite similar. In Sidama Zone, Ethiopia both the absolute and the relative expenses for a nutritious diet are higher and those for housing are lower than in both other locations.

The international or extreme poverty line is US\$ PPP 1.90 and the poverty line is US\$ PPP 3.20 per capita per day (World Bank 2015b). We converted this to US\$/AE/day and to the values for 2017 (World Bank 2018a). This means that in Lushoto US\$1.21/AE is equivalent to the extreme poverty line (Table 8). For Isingiro and Sidama zone those values are US\$ 1.08 and US\$ 1.41 , respectively. If we express the living income in the local US\$, the living income per AE is US\$ 1.51 in Lushoto, Tanzania, US\$ 1.31 in Isingiro, Uganda and US\$ 1.54 in Sidama, Ethiopia. Table 8 shows that in all 3 countries the living income is above the extreme poverty line, in Tanzania and Uganda by about $25 \%$ and in Ethiopia by $10 \%$.

\section{Discussion}

We adapted the living wage methodology of (Anker and Anker 2017b) and present a Living Income Methodology for rural households. We further developed a set of simple tools for rapid, transparent and consistent benchmarking. Along with this methods paper, we provide the survey tool (Living Income Survey: Online Resource 2) and the Living Income Diet Tool for calculating a nutritious diet at minimum cost (Online Resource 3 and 4). Both are accessible via a graphical user interface. The methodology was tested in three rural areas in the East African highlands: Lushoto District of Tanzania, and Isingiro District of Uganda, and Sidama Zone in Ethiopia. Below we first discuss the results obtained, second we compare our findings with other estimates of living income from developing countries, and third we reflect on the adaptations we have made to the method for estimating living income.

Table 6 Overview of the estimated health care costs (US\$ PPP) per reference household (RH) per year for rural areas in Lushoto District, Tanzania, Isingiro District, Uganda and Sidama Zone, Ethiopia for 2017

\begin{tabular}{llll}
\hline Cost item & $\begin{array}{l}\text { Lushoto District, } \\
\text { Tanzania }\end{array}$ & $\begin{array}{l}\text { Isingiro District, } \\
\text { Uganda }\end{array}$ & $\begin{array}{l}\text { Sidama Zone, } \\
\text { Ethiopia }\end{array}$ \\
\hline Basic health care insurance & US\$ PPP/RH/year & n.a. & n.a. \\
Doctor consultation, public & 12 & 64 & - \\
Medicine from pharmacy & Covered by insurance & 63 & - \\
Laboratory (self-)test & 36 & 4 & 89 \\
Total health care costs & - & 131 & 89 \\
Total health care cost & 48 & & 0.05 \\
\hline
\end{tabular}


Table 7 Overview of the estimated education costs (US\$ PPP) for a reference household (RH) per year, in rural areas of Lushoto District, Tanzania, Isingiro District, Uganda and Sidama Zone, Ethiopia for 2017

\begin{tabular}{llllll}
\hline Cost item & & Lushoto District, Tanzania & Isingiro District, Uganda & Sidama Zone, Ethiopia & Unit \\
\hline Primary education & Clothing & 54 & 28 & 71 & US\$ PPP/child/year \\
& Materials & 62 & 1303 & 40 & US\$ PPP/child/year \\
& Fees & 14 & 115 & - & US\$ PPP/child/year \\
& Duration & 7 & 7 & 6 & Year \\
Lower secondary education & Clothing & 62 & 95 & 96 & US\$ PPP/child/year \\
& Materials & 77 & 182 & 66 & US\$ PPP/child/year \\
& Fees & 27 & 147 & - & US\$ PPP/child/year \\
Full costs per child & Duration & 4 & 4 & 4 & Year \\
Average costs per child per year & & 1576 & 3630 & 1316 & US\$ PPP/child \\
Children per RH & 88 & 3 & 202 & 43 & US\$ PPP/child/year \\
Total education costs & 263 & 2.6 & 312 & Children/RH \\
Total education costs & & 0.22 & 0.38 & US\$ PPP/RH/year \\
\hline
\end{tabular}

${ }^{a}$ Full costs per child for 10 or 11 years of education, divided by 18 years of parental financial responsibility

\subsection{Living income in the case study areas}

Both for the Lushoto, Tanzania and Isingiro, Uganda, the living income was estimated to be 1.25 times the international poverty line of $1.90 \mathrm{US} \$ \mathrm{PPP} /$ person/day, the generally accepted benchmark for low-income countries, while in Sidama, Ethiopia it was $10 \%$. This suggests that rural households in low-income countries require an income above the international poverty line in order to comply with all their basic human rights for nutritious food, healthy housing, decent health care, sufficient education and other essential needs.
This analysis also shows that one general poverty line (US\$ 3.20 per capita per day) or international poverty line (US\$ 1.90 per capita per day) does not adequately reflect the basic rural human needs in different regions. Having said that, if a generally applicable benchmark is required, the poverty line is more realistic than the international or extreme poverty line, also for rural areas in low-income countries.

In rural Tanzania the living income in 2017 of US\$ 4.04 was more than double the national poverty line of US\$ 1.60 PPP/AE/day (National Bureau of Statistics Tanzania 2015). This difference between the living income and national

Table 8 The estimated living income in US\$ PPP/AE/day for a reference household in Lushoto District, Tanzania, Isingiro District, Uganda, and Sidama Zone, Ethiopia for 2017

\begin{tabular}{llll}
\hline & Lushoto District, Tanzania & Isingiro District, Uganda & Sidama Zone, Ethiopia \\
\hline Cost item & & US\$ PPP/AE/day & $1.57(44 \%)$ \\
Food & $1.64(41 \%)$ & $1.43(37 \%)$ & $0.81(23 \%)$ \\
Housing & $1.00(25 \%)$ & $0.85(22 \%)$ & $0.05(1 \%)$ \\
Health care & $0.04(1 \%)$ & $0.10(3 \%)$ & $0.16(5 \%)$ \\
Education & $0.22(6 \%)$ & $0.38(10 \%)$ & $1.19(18 \%)$ \\
Other NFNH & $0.73(18 \%)$ & $0.69(18 \%)$ & $0.86(24 \%)$ \\
NFNH & $0.99(25 \%)$ & $1.16(30 \%)$ & $0.36(10 \%)$ \\
Unforeseen & $0.40(10 \%)$ & $0.38(10 \%)$ & $3.60(100 \%)$ \\
Total living income & $4.04(100 \%)$ & $3.82(100 \%)$ & 1.41 \\
& & Local value US\$/AE/day & 2.30 \\
Extreme poverty line & 1.21 & 1.08 & 1.54 \\
Poverty line & 1.98 & 1.76 & 1.32 \\
Living income & 1.51 & & \\
\hline
\end{tabular}

The relative share of each item in the total living income is given between brackets. Poverty lines and living income in local US\$ in 2017

${ }^{a}$ based on US\$ 1.90 PPP per capita per day in 2011 (World Bank 2015b), converted to 2017 (World Bank 2018a)

${ }^{\mathrm{b}}$ based on US\$ 3.20 PPP per capita per day in 2011 (World Bank 2015b), converted to 2017 (World Bank 2018a) 
poverty line is likely due to differences in the data used, the bundle of goods and the year of assessment. The food basket at local or regional scale may differ from the national food basket. As food comprises some $50 \%$ of the living income in low-income countries, the national and regional living income may very well differ (Appleton 2003). The national poverty line includes a daily energy intake of $2200 \mathrm{kcal}$ per adult equivalent, against $2500 \mathrm{kcal} / \mathrm{AME}$ in the Living Income Methodology to account for heavy labour activities. The costs for non-food items in the national poverty line are based on the current food cost of the poorest $25 \%$ of the population and no allowance for clothing and housing rent are included. The national poverty benchmark is primarily based on actual household expenditure data, whereas the living income is based on expenditures required to supply all required goods and services and provide a nutritious diet, based on basic human rights. This can result in essential differences, as illustrated by the education costs. The living income budget for education was US\$262 PPP/RH/year. This is six times the actual household expenditure of US\$ $43 \mathrm{PPP} / \mathrm{HH} /$ year (National Bureau of Statistics Tanzania 2014). Decent education makes up $5 \%$ of the total living income budget, as compared with $1 \%$ of the current household expenditure. This is in line with our findings that interviewees rarely incurred costs for all of the items listed. Most households reported expenditures only on strictly necessary items (e.g. uniform, registration and security fee) and saved on optional items such as books. Early drop-out rates from school are high in Tanzania - which could potentially be a consequence of the expenditure saving strategy of resource-poor households. This example underlines the importance of a decent living as a basis for assessing living income and to avoid current expenditures wherever possible.

These same considerations hold for other national poverty lines. Comparing data across years and regions or countries requires conversion into comparable units, such as US\$ PPP for a specific year. The difference between US\$ 1.47 PPP in 2011 and 1.60 in 2017 is only 9\% over 6 years. However, if not corrected for inflation and exchange rates large fluctuations over time may occur especially in economically unstable, low-income countries. This is also true for the international poverty line of US\$ PPP 1.90/capita/day, last reviewed in 2011 and increased from US\$ PPP 1.25/capita/day in 2005. The international poverty line is only updated intermittently, but national poverty lines are updated when new national survey data become available (World Bank 2015b).

\subsection{Comparison of living income benchmarks}

The living income for all three cases was compared with ten other living income benchmarks for rural areas assessed by the Global Living Wage Coalition (GLWC) using the Anker Methodology (Fig. 2; data overview in Online Resource 5).
All living income estimates were converted from national currency to US\$ PPP, from per full time worker to per adult equivalent and from the year of study to 2017 to make them comparable across countries. The living income estimates for Lushoto District, Tanzania and Isingiro District, Uganda, are in the same order of magnitude as benchmarks in other rural areas in East African countries, such as Mount Kenya in Kenya and Mulanje District and Thyolo District in Malawi (Fig. 2a). Tanzania, Uganda and Malawi are low-income countries; Kenya used to be a low-income country before it officially graduated to be a lower-middle income country in 2014 - just before the study in 2015 (World Bank 2018c) for which an international poverty line of US\$ 3.20 was set (Jolliffe and Prydz 2016). The living income in Ethiopia, also a low-income country, is higher, but still at the lower end of the range. Ghana, Malawi, Kenya, Tanzania, Uganda and Ethiopia are among the 15 poorest countries on which the World Bank based the international poverty line in 2011 (Chen and Ravallion 2010). All other included studies were from rural areas in lower-middle income and upper-middle income countries, and these higher development levels are reflected in higher living income benchmarks ranging between 7.60 US\$ PPP/AE/day (Bhadohi, Uttar Pradesh, India) and 15.40 US\$ PPP/AE/day (Minas Gerais South/ Southwestern Mesa Region, Brazil).

As shown in Fig. $2 b$ the share of different cost categories (food, housing, NFNH, and unforeseen) in the total living income following our methodology was within the range found for the countries assessed by the Anker Methodology, but the share of the food costs was at the lower end. This is probably due our procedure of minimizing the cost of a nutritious diet, instead of considering only commonly purchased foods. Unfortunately, we do not have data in some of the countries assessed by the Anker Methodology, so we are not able to give a final direct comparison.

\subsection{Reflection and limitations of the living income methodology}

The Living Income Methodology described in this paper allows a rapid benchmarking of the living income in a rural area in Africa or in other low-income countries. It took about one day to prepare for the data collection, provided the enumerator is familiar with the study area, three days for data collection, one - two days for data analysis and reporting. So overall we found that an assessment of Living Income can be completed within 5-7 working days, if survey data are available. If not, additional time is required to review existing databases. In developing the Living Income Methodology we sought to balance detail and rapidity for each issue. Thus some simplifications and short cuts were made compared with the Anker Methodology (Anker 2006; Anker and Anker 2017b), but other items were included more explicitly, such as costs for 


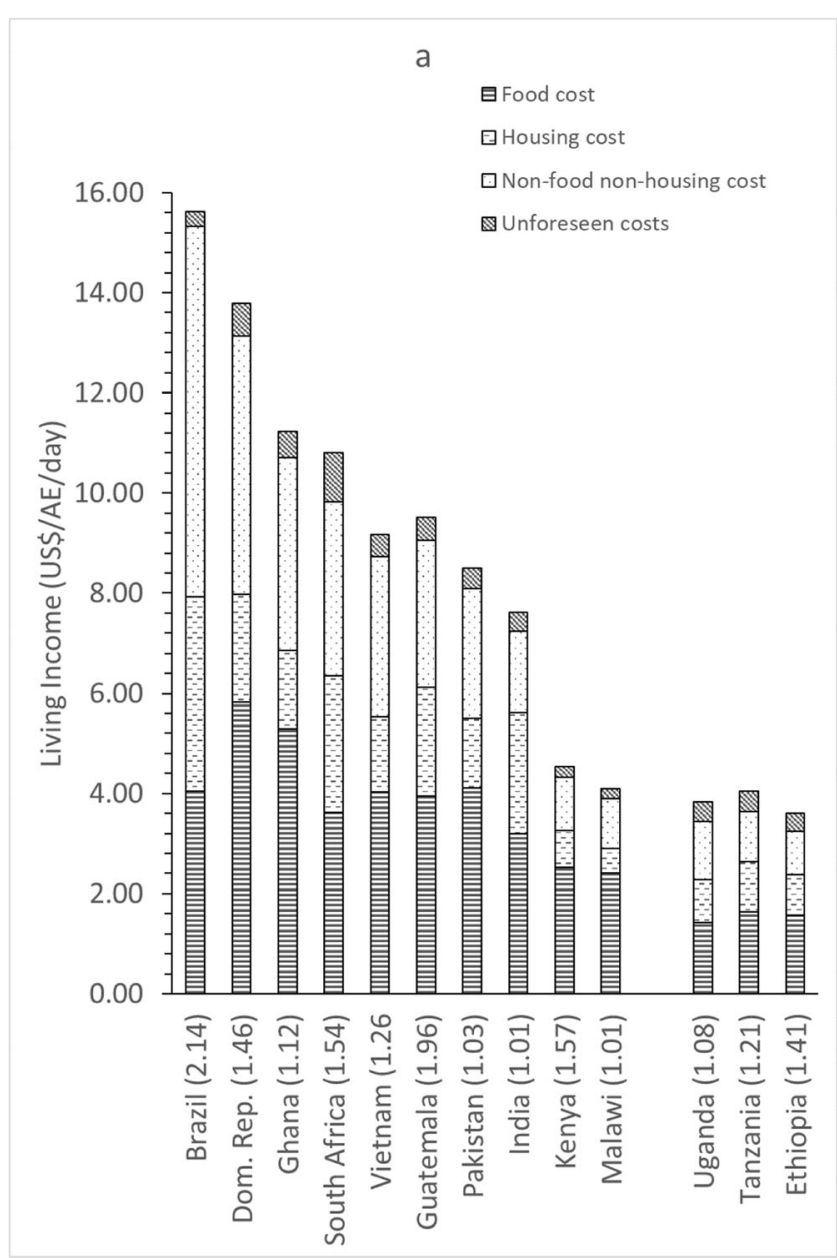

Fig. 2 Estimated living income (a) and the relative contribution of cost items to the total living income (b) of rural areas in Tanzania (Lushoto District), Uganda (Isingiro District) and Ethiopia (Sidama zone) using the Living Income Methodology explained in this paper, and of 10 living income studies prepared for the Global Living Wage Coalition (GLWC) using the Anker Methodology in rural areas of Brazil (De Freitas Barbosa et al. 2016), Dominican Republic (Anker and Anker

health care and education (Online resources 1-4). Given the importance of good health care and education for achieving a decent living, we explicitly address the local situation instead of using a relative share. Some data are difficult to assess, such as the quality of health care and education. We assumed that local services for both education and health care meet the human needs. This is examined in the interviews and focus group discussions and costs can be adapted based on real data if needed. In reality, the quality of local education and health care in low-income countries is sadly lacking. As one example, many families in Lushoto, Tanzania indicated they would prefer to send their children to private schools and to use private hospitals if they could afford to - which would more than double the living income. However, we felt we had no choice other than to accept that the education and medical care provided was designed to meet basic human needs. Local education and health care are the responsibility of local/

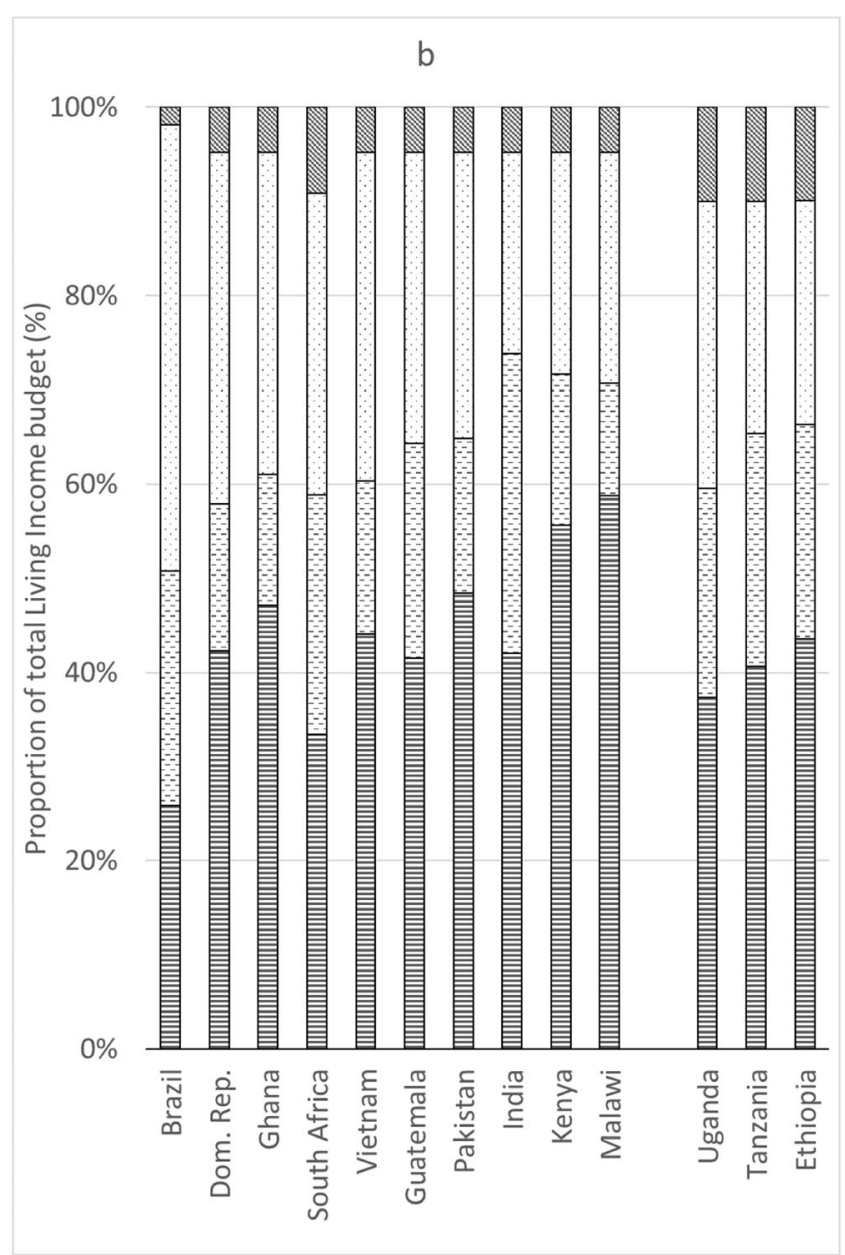

2013b), Ghana (Smith et al. 2017), South Africa (Anker and Anker 2013a), Vietnam (Trang and Binh 2017), Guatemala (Voorend et al. 2018), Pakistan (Sayeed and Dawani 2017), India (Mamkoottam and Kaicker 2016), Malawi (Anker and Anker 2014b), and Kenya (Anker and Anker 2017a). Between brackets the extreme poverty line US\$ 1.90 PPP expressed in the local US\$ value and converted to 2017. See Online Resource 5 for data overview

national governments. Without functional institutions for both no level of income is sufficient to meet the basic human rights of the local people.

We set the margin for Other NFNH goods and services at $20 \%$. This is an average of current household expenditure of some SSA countries. This is questionable as it includes current expenditures which we wanted to avoid. We are unsure how this compares with minimum costs, and with other regions, so this may need further investigation. We set the Unforeseen costs at $10 \%$ allowing for expenses that we might have cut too short. In general, collection of reliable data is the Achilles' heel of any survey-based method which means that careful triangulation with different sources is needed. Our methodology is no exception to this, and being a rapid assessment, this requires careful attention.

The unit in which income and poverty standards are expressed differs. We expressed the living income per adult 
equivalent, in contrast to the international poverty line (which is expressed as income per capita), to the Anker Methodology (living wage per worker) and to the Living Income Community of practice (living income per reference household). Calculating the indicator on a per capita basis does not cover the differences between children and adults. The expression per worker needs the number of people in the household actually working, which is very difficult to assess and fluid in a rural setting with seasonal work on- and off-farm in contrast to a commodity production setting which was the basis for the living wage definition. The expression per reference household represents a single average value, whereas in rural areas the composition of households is highly diverse, or more reference households need to be identified (Rusman et al. 2018). We chose to express the indicator as an adult equivalent (AE), based on the presence of the number of adults and children below 18 years, for two reasons. First because it is easy to assess. Second, and more importantly, because it facilitates comparison among households of different composition within a region. The component food costs is calculated per adult male equivalent, as food requirements are age and gender specific and subsequently converted into adult equivalent. Specifically for low-income countries, where food constitutes a relatively large part of the living income, this is appropriate (World Bank 2018b).

The Living Income Survey Tool provided good guidance on the questions, adequate registration of the data and rapid analysis once collected. Our assessment of the living income is based on essential human rights, so it is of major importance to stick to those issues and not to be misled by current habits, which easily occurs when collecting data. For instance, selecting the most commonly bought foods as in the Anker Methodology, or using current education expenditure does not necessarily allow calculation of the cost of a nutritious diet, or of the real cost of education to secondary level. The Living Income Tool assists in collecting the required data by using clear and explicit guidelines, questions and formats.

The Living Income Diet Tool behaves as expected and intended: it meets nutritional demands at the lowest cost based on the data collected on the cost of foods available in the location (Online Resource 3). A limitation is that focusing on the cheapest foods per food group does not take account of the nutrition density of a food. It might be cheaper to buy a more expensive food if a smaller amount would be required. This would require a price per ingredient of a food (e.g. per $\mathrm{kcal}$ or per $\mathrm{g}$ protein) for each food. In addition, the composition of diets is sometimes questionable from a consumption perspective, e.g. the large number of eggs per day in Ethiopia (Table 3). We set a $10 \%$ margin above the basic costs of a nutritious diet to allow modification of the diet to respect individual preferences. For a study more focused on nutrition of rural households, this tool would not be sufficiently detailed. For our purpose, that is assessing the living income of a rural household in a given region of a developing country, we consider the Living Income Diet Tool to be sufficient, based on our results, analysis and sensitivity analysis (Online resource 3).

The Anker Methodology is often applied to households who produce internationally-traded commodities such as in cocoa, coffee and tea in order to derive wages which business would have to pay farmers, so that they can earn a decent living (Rusman et al. 2018; Tyszler et al. 2018). Although the Anker Methodology was used in specific rural-urban and rural settings such as in Kenya (Anker and Anker 2014a, 2017a), the results were used to compare price levels between regions to show that the living income assessed is representative for most of rural Kenya. This facilitates the use of the living income by commercial companies in commodity chains, which is one of the goals of the Living Income Community of Practice (S. Daniels and K. Komives, personal communication, 2019). The data collection in the Anker Methodology reverts more often to national statistics and surveys, e.g. for labour participation. Our Living Income Methodology is intentionally focused on local data and surveys to benchmark a minimum income that rural households would need to earn in a given locality. This income could be derived from their own farming activities, from selling their labour locally, or from other types of employment.

We do not explicitly address labour input, as the living income benchmark refers to a daily monetary value required per AE, irrespective of the length of a working day. In the Anker Methodology the number of hours in a working day has to be mentioned, but it is not limited (Anker and Anker 2017b). For wages in commodity production this is a serious shortcoming. However, our local benchmark serves a different purpose than a (national) living income benchmark for commodities. For instance, our methodology can be used to assess the potential impact of a wide variety of rural development interventions on the households' incomes, such as subsidies on inputs, technology development, farmer organization to improve market access, etc. or to assess the minimum land area that would be required to achieve a living income from farming. If projects propose investment in farming activities the required labour input per day needs explicit attention, to avoid falling into the trap of implicitly assuming 12 or $16 \mathrm{~h}$ work days.

More case studies in the same regions as where the Anker Methodology was applied will clarify robustness of our Living Income Methodology, but given the results and comparisons obtained to date we are confident that it can be applied to rural areas in low-income countries.

\subsection{Future use and developments}

The Living Income is gaining importance for NGOs, governments and companies to support development of rural areas 
(Gneiting 2018; Huetz-Adams et al. 2017). For a good overview in variation of the living income across rural areas, countries and regions, it would be worthwhile to record all studies in a central (web) database, where case studies can be stored and viewed publicly. We propose that the regular inventories and surveys in agricultural research and development, such as the RhoMIS survey (Hammond et al. 2017) are extended to include data that enable i) calculation of the living income at the local level, better reflecting a poverty threshold than a worldwide international benchmark and ii) assessment of households against the living income. Our living income methodology can provide the basis for such an extension. Subsequently, assessment of development options for smallholder farmers can get a consistent and consolidated basis.

The tools of the Living Income Methodology described in this paper offer a consistent harmonized approach. They are easy to use and results are immediately calculated. It can be expanded from rural to urban areas and from less-developed to developed countries. A next step we are taking is to deploy the living income bench mark to analyse the role of agriculture in rural livelihoods and sustainable development. How large do farms need to be to provide a living income from agriculture? Currently we are addressing this question for six regions in sub-Saharan Africa, including the three locations presented in this study, based on household data collected in RHoMIS. This will support the identification of the configuration of technologies and management practices of farming systems that are best adapted to the local conditions.

\section{Conclusions}

Through this paper, we present the Living Income Methodology, as adapted from the Anker Living Wage Methodology, to rapidly estimate the living income for rural households in a specific area and time. Assessment of a living income in any given location requires about one week of fieldwork. We express it per adult equivalent per day (AE/day). The three case studies showed that in 2017 in Lushoto District, rural Tanzania, the living income is US\$ PPP $4.04 \mathrm{AE} /$ day, in Isingiro District, rural Uganda, it is 3.82 and in Sidama Zone, rural Ethiopia, it is 3.60. This clearly demonstrates that an income around the extreme poverty line of US\$ PPP 1.90 , although this is per capita, is insufficient to meet the basic human rights for a decent living.

The Living Income Methodology provides ample opportunities to derive a transparent local benchmark that can be used, for instance, for assessing development opportunities of rural households, by employers in rural areas, including farmers hiring in labour, while respecting basic human rights on a decent living. It can be used to reflect on progress of rural households in low-income countries on their aspired path out of poverty. It further provides a meaningful benchmark to measure progress on SDG1, to eliminate poverty and SDG2, zero hunger and sustainable food systems, allowing for explicit consideration of the local context.

Acknowledgements We thank six referees for their critical reading and comments on earlier versions of the manuscript that helped us improve both the methods of calculation and the explanation. All errors and omissions remain the responsibility of the authors. This research was funded through various sources: strategic investment of the Plant Production Systems group, University of Wageningen, the Bill \& Melinda Gates Foundation through the project N2Africa: Putting Nitrogen Fixation to Work for Smallholder Farmers in Africa (www.N2Africa.org) and a grant from the NWO-WOTRO Strategic Partnership NL-CGIAR. We are grateful to IITA Dar es Salaam data collection team: Abby Gamba, Bakari and Augustino, NARO and IITA Uganda (Godfrey Taulya) for using Banana Agronomy Socio-Economic survey data for the reference household, David Verhoog, Wageningen Economic Research for advice and checking the conversion calculations of the economic data to one year for all countries.

\section{Compliance with ethical standards}

Conflict of interest The authors declared that they have no conflict of interest

Open Access This article is licensed under a Creative Commons Attribution 4.0 International License, which permits use, sharing, adaptation, distribution and reproduction in any medium or format, as long as you give appropriate credit to the original author(s) and the source, provide a link to the Creative Commons licence, and indicate if changes were made. The images or other third party material in this article are included in the article's Creative Commons licence, unless indicated otherwise in a credit line to the material. If material is not included in the article's Creative Commons licence and your intended use is not permitted by statutory regulation or exceeds the permitted use, you will need to obtain permission directly from the copyright holder. To view a copy of this licence, visit http://creativecommons.org/licenses/by/4.0/.

\section{References}

Anker, R. (2006). Living wages around the world. A new methodology and international comparable estimates. International Labour Review, 145(4), 309-338.

Anker, R., \& Anker, M. (2013a). Living wage for rural South Africa with focus on wine grape growing in Western Cape Province. (pp. 46): Fairtrade International.

Anker, R., \& Anker, M. (2013b). Living wage report for rural Dominicam Repubic with focus on Banana growing area of the north. Report. (pp. 37): Fairtrade International, Social Accountability International.

Anker, R., \& Anker, M. (2013c). A shared approach to estimating living wages; short description of the agreed methdology. Global Living Wage Coalition.

Anker, R., \& Anker, M. (2014a). Living wage for Kenya with focus on fresh flower farm area near Lake Naivasha. (pp. 68): Fairtrade International, Sustainable Agriculture Network, Rainforest Alliance, UTZ Certified.

Anker, R., \& Anker, M. (2014b). Living wage for rural Malawi with focus on tea growing area of southern Malawi. (pp. 70): Fairtrade 
International, Sustainable Agriculture Network, Rainforest Alliance, UTZ Certified.

Anker, R., \& Anker, M. (2017a). Living wage report Kenya with a focus on rural Mount Kenya area. Context provided in horticulture industry. G.L.W. Coalition (Ed.), Series 1. report 10 (pp. 51). https://doi. org/10.4337/9781786431462.

Anker, R., \& Anker, M. (2017b). Living wages around the world. Manual for measurement. Northampton: Edward Elgar Publishing.

Appleton, S. (2003). Regional or national poverty lines? The case of Uganda in the 1990s. discussion paper No 2003/90: World Institue for Development Economics Research, UN University.

Atkinson, A. B., Rainwater, L., \& Smeeding, T. M. (1995). Income distribution in OECD countries. Evidence form the Luxembourg income study. OECD Social Policy Studies No. 18 (pp. 159). Paris: OECD

Beal, T., Massiot, E., Arsenault, J. E., Smith, M. R., \& Hijmans, R. J. (2017). Global trends in dietary micronutrient supplies and estimated prevalence of inadequate intakes. PLoS One, 12(4), e0175554. https://doi.org/10.1371/journal.pone.0175554.

Bhattacharyya, M. (2018). Benchmarks for living wage and living income: Managing a study from set-up to release. Report (pp. 48): On-Up LLC, GIZ, Living Income Community of Practice.

Chen, S., \& Ravallion, M. (2010). The developing world is poorer than we thought, but no less succesful in the fight against poverty. The Quarterly Journal of Economics, 125(4), 1577-1625.

Croes, P. R., \& Vermeulen, W. J. V. (2016). In search of some income refernce points for LCA using a country level benchmark (part2): Fair minimum wage. A contribution to the Oiconomy project. The International Journal of Life Cycle Assessment, 21(3), 363-377. https://doi.org/10.1007/s11367-015-1017-1.

De Freitas Barbosa, A., Barbosa e Silva, M., Cadia Veiga, J. P., \& Zacareli, M. A. (2016). Living wage report for rural Brazail, Minas Gerais south/Southwestern region with focus on the coffee sector for context. Report 5. (pp. 43): Global Living Wage Coalition.

De Jager, I., Abizari, A.-R., Douma, J. C., Giller, K. E., \& Brouwer, I. D. (2017). Grain legume cultivation and children's dietary diversity in smallholder farming households in rural Ghana and Kenya. [journal article]. Food Security, 9(5), 1053-1071. https://doi.org/10.1007/ s12571-017-0720-0.

Dikhanov, Y., Hamadeh, N., Vigil-Oliver, W., Degefu, T. B., \& Song, I. (2017). Poverty specific purchasing power parities in Africa. In D. E. World Bank Group, Development Data Group (Ed.), Policy Research Working Paper (Vol. 8150, pp. 23). Washington DC: World Bank.

Falconnier, G. N., Descheemaeker, K., Van Mourik, T. A., Sanogo, O. M., \& Giller, K. E. (2015). Understanding farm trajectories and development pathways: Two decades of change in southern Mali. Agricultural Systems, 139, 210-222. https://doi.org/10.1016/j.agsy. 2015.07.005

FAO (2018). International network of food data systems (INFOODS). http://www.fao.org/infoods/infoods/tables-and-databases/en/ Accessed 01-05-2018.

FAO (2020). Indicators from household surveys. http://www.fao.org/ faostat/en/\#data/HS Accessed 02-03-2020.

FAO, \& Ethiopian Health and Nutrition Research Institute. (1995). Food compostion table for use in Ethiopia, Part IV. Rome: FAO.

FAO/WHO/UNU (2001). Human energy requirements. Report of a joint FAO/WHO/UNU Expert consultation, Rome, 17-24 October 2001. Food and Nutrition Technical Report Series 1 (pp. 103): FAO.

Ferreira, F. H. G., Chen, S., Dabalen, A., Dikhanov, Y., Hamadeh, N., Jolliffe, D., Narayan, A., Prydz, E. B., Revenga, A., Sangraula, P., Serajuddin, U., \& Yoshida, N. (2016). A global count of the extreme poor in 2012: Data issues, methodology and initial results. The Journal of Economic Inequality, 14(2), 141-172. https://doi.org/ 10.1007/s10888-016-9326-6.
Gneiting, U. (2018). A living income for small-scale farmers: Tackling unequal risks and market power. OXFAM discussion paper. (23 pp) Oxford, OXFAM GB.

Grillo, J. (2018). From living wage to living income. Considerations for the use of the Anker methodology for calculating living wages to infomr living income estimates. (pp. 13): https://www.livingincome.com/papersandreports, ISEAL Alliance, Sustainable Food Lab, GIZ. Accessed 10 Jul 2019.

Gustavsson, J., Cederberg, C., Sonesson, U., Otterdijk, R., \& Meybeck, A. (2011) Global food losses and food waste. Extent, causes and prevention. In International congress SAVE FOOD!, Dusseldorf, Germany, 2011 (pp. 37): Swedish Institute for Biotechnology, FAO.

Hammond, J., Fraval, S., van Etten, J., Suchini, J. G., Mercado, L., Pagella, T., Frelat, R., Lannerstad, M., Douxchamps, S., Teufel, N., Valbuena, D., \& van Wijk, M. T. (2017). The Rural Household Multi-Indicator Survey (RHoMIS) for rapid characterisation of households to inform climate smart agriculture interventions: Description and applications in East Africa and Central America. Agricultural Systems, 151, 225-233. https://doi.org/10. 1016/j.agsy.2016.05.003.

Hotz, C., \& Brown, K. H. (2004). Assessment of the risk of zinc deficiency in populations and options for its control. Food and Nutrition Bulletin, 25 no 1 (supplement 2), S91-S202.

Huetz-Adams, F., Laven, A., Bymollt, R., \& Tyszler, M. (2017). Towards a living income calculation for cocoa households in Ghana and Cote d'Ivoire. Paper presented at the International Symposium on Ccocoa Research (ISCR), Lima, Peru, 13-17 November 2017.

ILO. (2008). ILO declaration on social justice for a fair globalization (p. 25). Geneva: Internationa Labour Organization.

IOM. (2001). Dietary reference intakes for vitamin a, vitamin $K$, arsenic, boron, chromium, copper, iodine, manganese, molybdenum, nickel, silicon, vanadium and zinc. Institute of Medicine (US) panel on micronutrients. Washington DC: National Academy Press.

ISEAL Alliance (2020). https://www.isealalliance.org/ Accessed 02-032020

Jolliffe, D., \& Prydz, E. P. (2016). Estimating international poverty lines from comparable national thresholds. Policy Research Working Paper 7606 (pp. 36): Washington DC: World Bank.

Jolly, R. (1976). The world employment conference: The enthronement of basic needs. Development Policy Review A9, 2, 31-44. https://doi. org/10.1111/j.1467-7679.1976.tb00338.x.

Kennedy, G., Ballard, T., \& Dop, M. (2010). Guidelines for measuring household and individual dietary diversity. (pp. 60). Rome: FAO.

Leonardo, W. J., van de Ven, G. W. J., Udo, H., Kanellopoulos, A., Sitoe, A., \& Giller, K. E. (2015). Labour not land constrains agricultural production and food self-sufficiency in maize-based smallholder farming systems in Mozambique. Food Security, 7(4), 857-874. https://doi.org/10.1007/s12571-015-0480-7.

Living Income Community of Practice (2020). Towards a decent standard of living for smallholder farmers. https://www.living-income.com Accessed 02-03-2020.

Lukmanji, Z., Hertzmark, E., Mlingi, N., Assey, V., Ndossi, G., \& Fawzi, W. (2008). Tanzania food composition tables (p. 272). Dar es Salaam: Muhimbili University College of Health and Applied Sciences, Tanzania Food and Nutrition Center, Department of Nutrition Harvard School of Public Health.

Mamkoottam, K., \& Kaicker, N. (2016). Living wage report for Bhadohi, Uttar Pradesh, India: Rural with context provided in the carpet weaving industry. Report 8. (pp. 44): Global living Wage Coalition.

Mellisse, B. T., van de Ven, G. W. J., Giller, K. E., \& Descheemaeker, K. (2017). Home garden system dynamics in southern Ethiopia. Agroforestry Systems, 92, 1579-1595. https://doi.org/10.1007/ s10457-017-0106-5. 
National Bureau of Statistics Tanzania (2014). Tanzania mainland household budget survey main report 2011/12. (pp. 201): Ministry of Finance, Dar es Salaam, United Republic of Tanzania.

National Bureau of Statistics Tanzania (2015). Tanzania - National panel survey 2012-2013, wave 3. (pp. 638): Ministry of Finance, Tanzania.

OECD (2011). What are equivalence scales? OECD project on Income Distribution. (pp. 2).

Rusman, A., Adelhart Toorop, R. de, Boer, J. de, \& Groot Ruiz, A. de (2018). Cocoa farmer income: The household income of cocoa farmers in cote d'Ivoire and strategies for improvement (p. 47). Amsterdam: Trueprice, Fairtrade.

Sayeed, A., \& Dawani, K. (2017). Living wage report for urban and rural Pakistan, Sialkot, north eastern Punjab with context provided in the sports ball manufacturing industry. Report 9. (pp. 52): https://www. globallivingwage.org/living-wage-benchmarks/rural-pakistan/: Global Living Wage Coalition. Accessed 20 Jul 2018.

Smith, S., Anker, M., \& Anker, R. (2017). Living wage report for lower Volta river area, Ghana: Context provided in the banana sector. Report 14. (pp. 61): https://www.globallivingwage.org/livingwage-benchmarks/ghana/ Global Living Wage Coalition. Accessed $20 \mathrm{Jul} 2018$.

Trang, S., \& Binh, T. (2017). Living wage report for rural Vietnam: Context provide in the seafood processing industry. Report 11. (pp. 53): https://www.globallivingwage.org/wp-content/uploads/ 2018/04/living-wage-report-rural-vietnam.pdf: Research Center for Employment Relations, Global Living Wage Coalition. Accessed $20 \mathrm{Jul} 2018$.

Tyszler, M., Bymollt, R., \& Laven, A. (2018). Analysis of the income gap of cocoa producting households in Ghana: Comparison of actrual incomes with the living income benchmark. Prepared for the Living Income Community of Practice 11-09-2018 (p. 39). Amsterdam: Royal Tropical Institute.

Uganda Bureau of Statistics (2014). National population and housing census 2014 - Provisional results. (pp. 73). Kampala, Uganda.

Uganda Bureau of Statistics (2016). The national population and housing census 2014 - Main report. (pp. 108). Kampala, Uganda.

UNDP (2014). Country economic brief - Ethiopia - analysis issue no. 1/Feb.2014. (pp. 15). www.et.undp.org; UNDP. Accessed $20 \mathrm{Jul}$ 2018.

UNESCO (2000). The right to education: Towards education for all throughout life. World education report 2000. (pp. 169): UNESCO.

United Nations. (2007). Indicators of sustainable develpment: guidelines and methologies (3rd ed.p. 99). New York: United Nations.

United Nations General Assembly (1948). Universal declaration of human rights. Resolution 2017 A (III) of December 1948 (pp. 6). New York: United Nations.

United Nations General Assembly. (2015). Transforming our world: The 2030 agensa for sustainable develpment. A/RES/70/1. (pp. 41). New York: United Nations.

United Nations, Department of Economic and Social Affairs, \& Population Division (2017). World population prospects: The 2017 revision, key findings and advance tables. Working paper no. ESAP/WP/248. (pp. 53). New York: United Nations.

USDA. (2007). USDA table of nutrient retention factors - release 6 (p. 18). Beltsville: Beltsville Human Nutrition Research Centre.

USDA (2018). USDA food composition databases. https://ndb.nal.usda. gov/ndb/ Accessed 01-05-2018.
Voorend, K., Anker, M., \& Anker, R. (2018). Living wage report for rural Guatemala. Central departments: Context provided in the coffee sector. Report 16. (pp. 69): Global Living Wage Coalition.

Wehmeyer, A. S., \& Rose, E. F. (1983). Important indigenous plants used in the Transkei as food supplements. Bothalia, 14(3/4), 613-615.

WHO/FAO (2003). Diet nutrition and the prevention of chronic diseases. Report of a joint WHO/FAO expert Consultaion, Geneva, 28 January - 1 February 2002. WHO technical report series 916 (pp. 160). Geneva, Switzerland.

WHO/FAO. (2004). Vitamins and mineral requirements in human nutrition, report of a joint FAO/WHO expert consultaion, Bangkok, Thailand, 21-30 september 1998 (2nd ed.). Geneva: WHO.

World Bank. (2014). Purchasing power parities and real expenditures of world economies: summary of results and findings of the 2011 International Comparison Program (p. 104). Washington, DC: World Bank.

World Bank (2015a). A measured approach to ending poverty and boosting shared prosperity: Concepts, data, amd the twin goals. Policy Research Report. Washington DC: World Bank.

World Bank. (2015b). Purchasing power parities and the real size of world economies: a comprehensive report of the 2011 international comparison program (p. 328). Washington DC: World Bank.

World Bank. (2016). The Uganda poverty assessment - report 2016. Farms cities and good fortune: assessing poverty reduction in Uganda from 2006 to 2013 (p. 178). Washington DC: World Bank.

World Bank (2018a). DataBank World Development Indicators. http:// databank.worldbank.org/data/reports.aspx?source=2\&series=PA.NUS. PRVT.PP\&country=GHA,BRA,ZAF,GTM,DOM,IND,KEN,MWI, PAK,ETH,UGA,TZA,VNM,USA, Accessed 20-08-2018.

World Bank (2018b). Poverty and shared prosperity 2018: Piecing together the poverty puzzle. In W. B. Group (Ed.), (pp. 201). Washington DC: World Bank.

World Bank (2018c). World Bank country and lending groups. https:// datahelpdesk.worldbank.org/knowledgebase/articles/906519world-bank-country-and-lending-groups, Accessed 01-05-2018. Washington DC: World Bank.

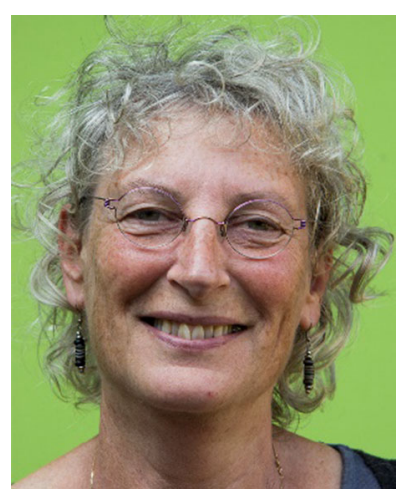

Gerrie van de Ven holds a $\mathrm{PhD}$ in Agricultural Science from Wageningen University. She is employed at the Plant Production Systems Group of that University. She combines research and teaching with a focus on farming systems analysis and optimization of land use systems related to all three dimensions of sustainability. Nutrient cycling, environmental impacts and indicators, the interaction between crops and livestock and economic consequences, both in the western world and in Africa, have her special attention. Her scientific work has built on tools such as systems analysis and modelling approaches, mainly at the farm and regional level. 


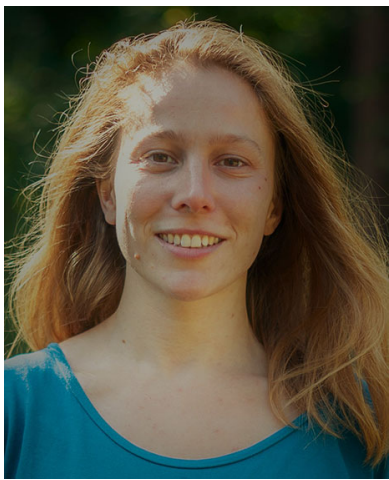

Anne de Valença holds a BSc. Biology (University of Amsterdam) and MSc. Organic agriculture with specialization in agroecology (Wageningen University). After these studies, she worked as research \& education assistant at the Plant Production Systems Group of Wageningen University \& Research. Her work there included the creation of a SDG Academy MOOC on sustainable agriculture and nutrition, and research on living income methodology for rural households. Currently, she works as Food \& Agriculture advisor at the World Wildlife Fund for Nature Netherlands (WWF-NL).

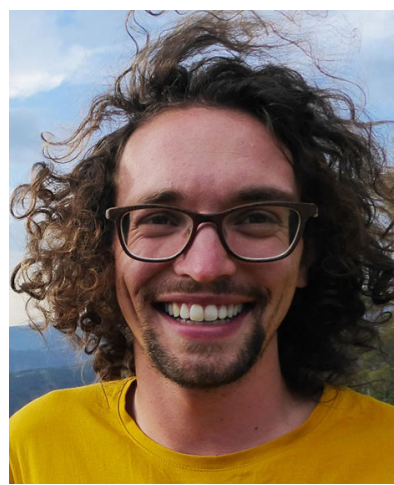

Wytze Marinus is a PhDcandidate at the Plant Production Systems group of Wageningen University. He holds and MSc in Plant Science. The title of his $\mathrm{PhD}$ project is "Towards more sustainable farming systems in the East African highlands", which he tackles from two angles. In multiple season co-learning cycles with groups of farmers in Kenya and Uganda he explores current opportunities for sustainable intensification and the impacts of using these for participating farmers. In a more theoretical approach, based on survey data, he assesses income from farming in current and future farming systems.

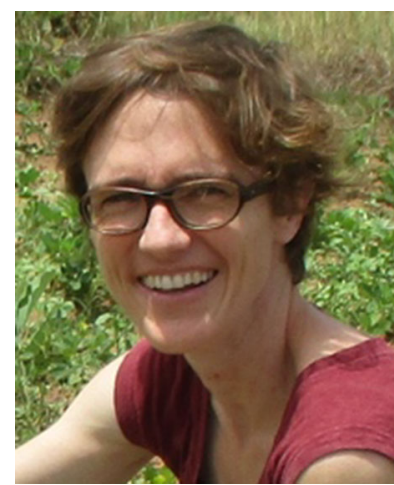

Katrien K.E. Descheemaeker is associate professor in the Plant Production Systems group of Wageningen University and Research (Netherlands). Her research focuses on farming systems analysis, resource use efficiency, natural resources management, soil-plant-animal interactions, and environmental sustainability, with a special interest in the functioning and dynamics of mixed crop-livestock systems. Current research combines experimental trial work with simulation modelling to identify and assess interventions for improved resource use efficiency and farm profitability, and reduced risks associated with climate and market variability. Across various projects on smallholder farming systems in sub- Saharan Africa, Dr. Descheemaeker and colleagues develop effective methods for participatory research with farmers and other stakeholders to increase the potential adoption and impact of technology and management options to increase farm productivity, food security and natural resource integrity.

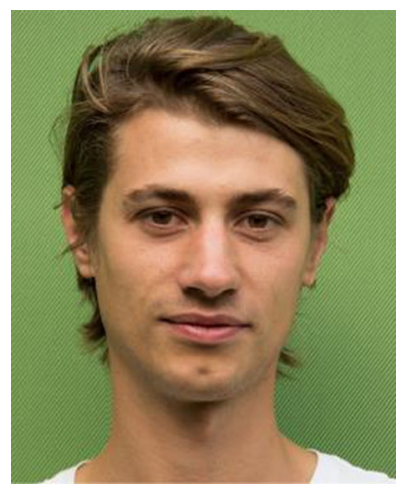

Willem Hekman worked as a research fellow in the Plant Production Systems research group at Wageningen University. He studied applied physics and obtained his MSc degree with research in quantum information theory. His interest in food production and food's role in society brought him to Wageningen University where he mainly worked on developing computer models to estimate theoretical crop production potentials.

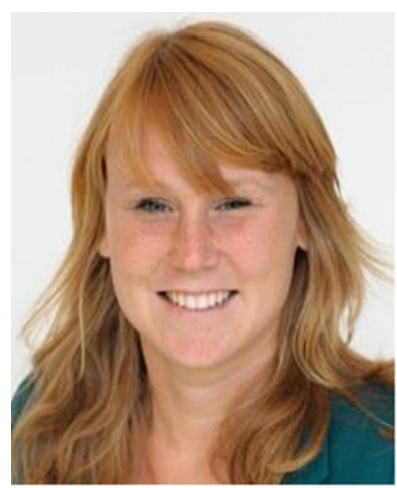

Ilse de Jager has a $\mathrm{PhD}$ from the Division of Human Nutrition and the Plant Production Systems group at Wageningen University, the Netherlands. She finished her $\mathrm{PhD}$ research in 2019, after obtaining her MSc degree in Human Nutrition. Her research focuses on impacts of agriculture on improving diets and nutritional status of vulnerable groups from rural households in sub-Saharan Africa, in particular focusing on the potential of grain legumes. She conducted her $\mathrm{PhD}$ research within the context of the agricultural development project N2Africa (www.N2Africa.org) that was one of the winning projects of the 2013 Harvesting Nutrition Contest initiated by the World Bank.

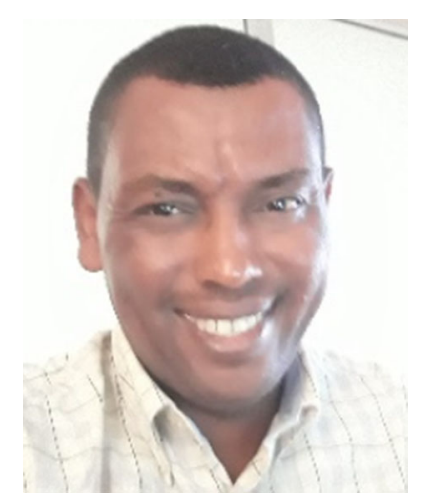

Beyene Teklu Mellisse works at Hawassa university, Ethiopia. Prior to joining Hawassa University, he served in Ethiopian Institute of Agricultural Research (EIAR) as a researcher. Mellisse has conducted research on forage agronomy, agricultural sustainability, farming system dynamics and food security and published in peer reviewed journals. His current research focuses on farming system dynamics and its implication on socioeconomic and ecological sustainability. He holds a $\mathrm{PhD}$ in System Agronomy/agricultural sustainability from Wageningen University, the Netherlands. 


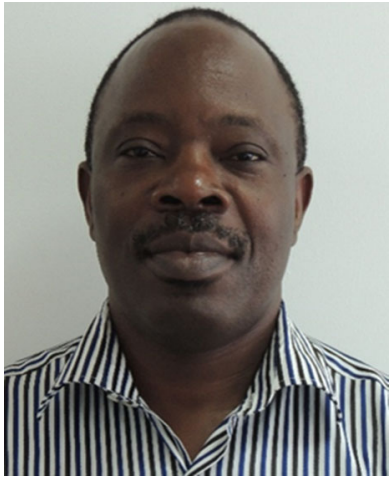

Frederick Baijukya is Farming System Scientist at International Institute of Tropical Agriculture (IITA) based in Dar es Salaam Tanzania. Formerly, he was Agronomist at Intentional Centre of Tropical Agriculture (CIAT), Nairobi office, and before that, he served as Principal Agricultural Office in the Department of Research and Development in the Ministry of Agriculture and Cooperative, Tanzania. He has worked extensively in different farming systems in East Africa with special focus on intensification and diversification of smallholder- agricultural systems, participating in different projects including 'Exploring trade-offs around farming livelihoods and the environment: the AfricaNUANCES framework and 'Putting nitrogen fixation to work for smallholder farmers in sub-Saharan Africa (N2Africa).

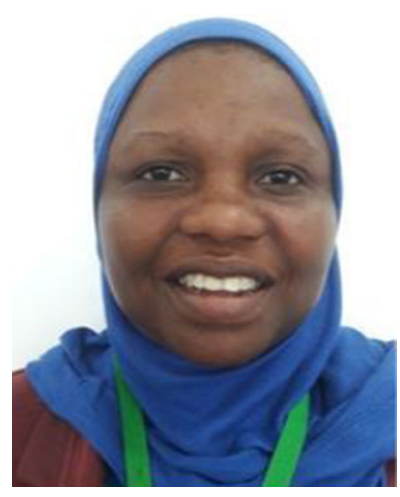

Mwantumu Omari is an Agricultural Economics at International Institute of Tropical Agriculture (IITA), based in Dar es Salaam Tanzania. Mwantumu has been working with IITA since 2012 in different capacities, first, as scaling specialist of Common Fund for Commodities program on "Small scale cassava processing and vertical integration of the cassava subsector in Eastern and Southern Africa -Phase II, and since July 2014, as business development officer under N2Africa Project "Putting Nitrogen Fixation to work for smallholders farmers in Africa" phase II in Tanzania. Mwantumu has more than 10 years' experience on working with national and International organizations in promoting agriculture technologies for income, food and nutrition security among small holder farmers in East Africa region.

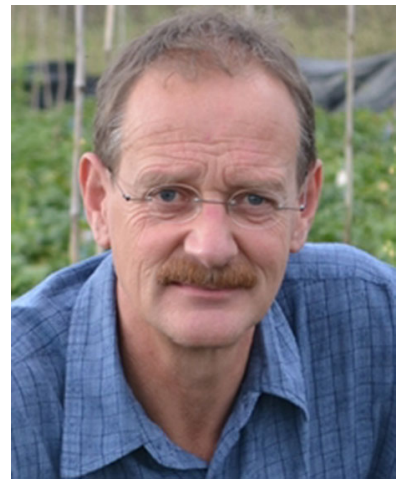

Ken Giller is Professor of Plant Production Systems at Wageningen University. He leads a group of scientists with profound experience in applying systems analysis to explore future scenarios for land use with a focus on food production. Ken's research has focused on smallholder farming systems in sub-Saharan Africa, and in particular problems of soil fertility and the role of nitrogen fixation in tropical legumes, with emphasis on the temporal and spatial dynamics of resources within crop/livestock farming systems and their interactions. His research interest is also in resource utilization efficiency and scaling in systems analysis, particularly on the role of nitrogen fixing legumes in provision of food, feed, fuel, and soil fertility in tropical farming systems. He is author of the standard text "Nitrogen Fixation in Tropical Cropping Systems" published in second edition in 2001. He leads a number of initiatives such as N2Africa - Putting Nitrogen Fixation to Work for Smallholder Farmers in Africa - http://www.n2africa.org/. N2Africa works to scale promising technologies through $>90$ public-private partnerships in eleven countries of sub-Saharan Africa. Ken is member of the Unilever Sustainable Sourcing Advisory Board. He is co-chair of the Thematic Network 7 on Sustainable Agriculture and Food Systems of the Sustainable Development Solutions Network (SDSN) of the United Nations. Ken joined Wageningen University as Chair of Plant Production Systems in 2001 after holding professorships at Wye College, University of London, and the University of Zimbabwe. 